\title{
35. PETROLOGY AND GEOCHEMISTRY OF SANDSTONES IN THE LOWER CRETACEOUS SUBMARINE FAN COMPLEX, DEEP SEA DRILLING PROJECT HOLE 603B'
}

\author{
D. R. Prezbindowski and Edward D. Pittman, Amoco Production Company²
}

\begin{abstract}
Diagenesis of the fine-grained, feldspathic sandstones in the Lower Cretaceous submarine fan complex cored in DSDP Hole 603B can be considered to have occurred in three stages: (1) replacement of matrix and framework grains by pyrite, siderite, phillipsite (?), and particularly by ferroan calcite; (2) dissolution of ferroan calcite and feldspars to produce secondary macroporosity; and (3) development of sparse feldspar and quartz overgrowths, and authigenic modification of remnant matrix. Only ferroan calcite is a volumetrically important diagenetic mineral phase (up to 50 vol. \%).

Matrix in thin sandstone turbidite deposits has been extensively replaced by ferroan calcite. Carbon stable isotope data suggest that organic diagenesis had only a minor influence on calcite precipitation. Oxygen stable isotope data indicate that the minimum average calcite precipitation temperature was $40^{\circ} \mathrm{C}$. Preliminary calculations show that steadystate diffusion of $\mathrm{Ca}^{++}$from the dissolution of nannoplankton skeletal material in the interbedded pelagic marls to the associated sandstones is a feasible transport mechanism.

A thick sandstone unit from $1234-1263 \mathrm{~m}$ sub-bottom is extensively replaced by calcite near the upper and lower contacts. Farther into the sand body away from the contacts, the sandstone has good secondary porosity resulting from the dissolution of ferroan calcite that partially replaced matrix and framework grains. The central portion of the thick sand appears to be a channel with high-energy clean sand. We believe that the channel provided a conduit for focused flow of diagenetic compactional fluids responsible for dissolution. Focused flow may be the result of the earlier lithification of the pelagic limestones and thin-bedded sandstones which, then formed vertical permeability barriers. Calcite dissolution has occurred and may still be occurring at temperatures less than $65^{\circ} \mathrm{C}$.
\end{abstract}

\section{INTRODUCTION}

Hole 603B penetrated and continuously cored a previously unknown Lower Cretaceous submarine fan complex (lithologic Subunit VA) on the lower continental rise $270 \mathrm{mi}$. (435 km) off Cape Hatteras (Fig. 1). This complex consists of terrigenous sandstone and claystone turbidite deposits interbedded with pelagic marls (Site 603 chapter, this volume). Selected sandstones are porous and in places friable (Fig. 2). The geologic setting and history preclude the possibility of meteoric water, soil-derived organic acids, or surface weathering affecting these sediments after deposition. Therefore, diagenetic events are believed to be related to in situ controls. Our purpose is to provide a survey study of the general diagenetic history of the sandstones and limestones using optical and electron microscopy, X-ray diffractometry, microprobe analytical techniques, stable isotopes, and organic geochemistry. The database ( 30 samples) is inadequate to address every diagenetic problem. We hope that this study will provide a basis for future, more definitive work.

\section{METHODS}

Oxygen and carbon stable isotope compositions of carbonate minerals were determined using the phosphoric acid technique first documented by McCrea (1950). All analyses were made on a Finnigan MAT 251 , constant-ratio mass spectrometer. The $20-100 \mathrm{mg}$ whole-rock sam-

\footnotetext{
${ }^{1}$ van Hinte, J. E., Wise, S. W., Jr., et al., Init. Repts. DSDP, 93: Washington (U.S. Govt, Printing Office).

2 Address (Prezbindowski, present address): International Petrology Research, 3228 East 15th St., Tulsa, OK 74104; (Pittman) Amoco Production Co., Research Center, P.O. Box 3385, Tulsa, OK 74102 .
}

ples were first vacuum roasted at $360^{\circ} \mathrm{C}$ for $1 \mathrm{hr}$. to remove volatile components. Results are referenced to the Chicago PDB standard unless otherwise indicated. Analytical error was found to be no greater than $\pm 0.2 \%$

Analyses of feldspars were made using a Kevex 8000-III energy-dispersive spectrometer attached to an Applied Research Laboratories SEMQ microprobe. This permitted use of a low-beam current to prevent loss of alkalis from the analysis area. Beam operating parameters were: excitation voltage, $20 \mathrm{kV}$; beam current, $1 \mathrm{nA}$ (measured in a Faraday cage); beam diameter $10 \mu \mathrm{m}$; and emission current, $125 \mu \mathrm{A}$. Counts were accumulated to a preset precision of $0.5 \%$ in a window set for $\operatorname{SiK} \alpha$. A minimum of two points per grain were analyzed and averaged. Analyses whose totals were less than $95 \%$ or more than $105 \%$ were rejected from the data set.

Calcite cement was also analyzed on an Applied Research Laboratories SEMQ microprobe with the following operating conditions: excitation voltage, $20 \mathrm{kV}$; emission current, $125 \mu \mathrm{A}$; beam current, $1 \mathrm{nA}$ (measured in a Faraday cage); spectrum acquisition time, $100 \mathrm{~s}$. The analytical totals suggest, and cross analyses of standards confirm, that analytical errors under these conditions are within $3-5 \%$ of the amount present.

All rock samples were pressure impregnated with a blue-dyed epoxy resin before thin sections were prepared. Thin sections were stained to facilitate recognition of carbonates and $\mathrm{K}$-feldspar using the techniques of Dickson (1966) and Bailey and Stevens (1960), respectively.

Vitrinite reflectance was determined on four samples using standard reflective light techniques discussed by Stach (1975). Elemental analytical techniques used for kerogen are comparable to those of Robinson (1969).

\section{PETROLOGY}

\section{Sandstones}

\section{Texture and Composition}

Sandstones of Subunit VA are predominantly finegrained, but range from very fine to medium-grained. 


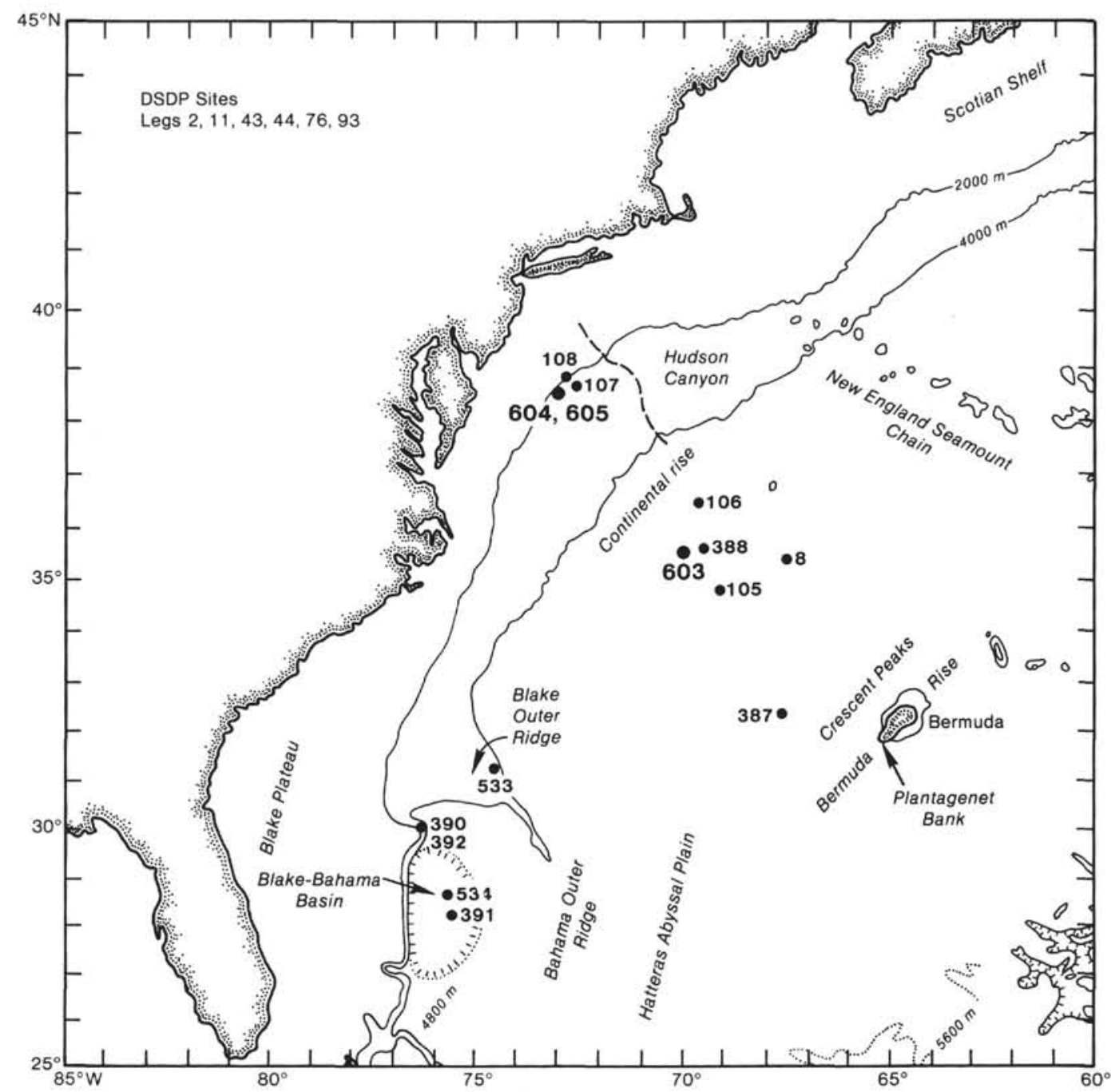

Figure 1. Location of DSDP Site 603 about $435 \mathrm{~km}$ ( $270 \mathrm{n}$. mi.) off the east coast of North America.

Typically, the subangular sand-sized components are embedded in an argillaceous matrix, which constitutes 0 $35 \%$ of the total rock and varies inversely with ferroan calcite that replaces the matrix. We interpret the matrix to be detrital. The clay particles are arranged in a faceto-face packing and appear to "flow" around framework grains because of compaction (Fig. 3). There is no evidence of delicate fibers or euhedral crystals that characterize authigenic clays (Wilson and Pittman, 1977). We also find no evidence of the type suggesteu by Dickinson (1970) to support phyllosilicate cement or pseudomatrix origins. If the matrix is diagenetic, it would have to be called epimatrix (Dickinson, 1970), because it lacks the clear evidence needed to classify the interstitial clay as phyllosilicate cement.

No attempt was made to separate the matrix for X-ray diffractometry because we felt the disaggregation process would also affect the sand-size lithic fragments. We did obtain X-ray diffraction data for the claystone "tails" of the turbidites, which should be representative of the detrital matrix in the sandstone (see section on finegrained rocks). Mixed-layer, randomly interstratified illite/smectite ( $80 \%$ expandable) is the dominant clay, al- though minor kaolinite, illite, and chlorite are also present.

Point-counts for 19 samples indicate the sandstones are arkoses and subarkoses in a modified Dott (1964) classification (Fig. 4). Framework grains and their mean composition as a percentage of the total rock include monocrystalline quartz $(29.6 \mathrm{vol} . \%)$, polycrystalline quartz $(4.7 \mathrm{vol} . \%)$, lithic fragments $(5.0 \mathrm{vol} . \%)$, K-feldspar $(8.7 \mathrm{vol} . \%)$, plagioclase $(4.8 \mathrm{vol} . \%)$, muscovite $(1.9$ vol. $\%)$, biotite $(1.5$ vol. \%), and other (1.1 vol.\%). Lithic fragments include plutonic igneous, schist, phyllite, shale, and altered volcanic. Zircon, tourmaline, pyroxene, glauconite, and collophane are the most common accessory minerals. Skeletal grains and woody debris are fragmented and sparse.

Composition of detrital plagioclase in Subunit VA based on microprobe analyses in three samples is shown in Figure 5. No plagioclase is more calcic than $\mathrm{An}_{26}$, and $45 \%$ of the grains are in the $\mathrm{An}_{0-5}$ modal class. Detrital plagioclase in modern deep-sea sands from passive and active tectonic settings has a wide range in composition: about one-third of the grains are more calcic than $\mathrm{An}_{40} ; 19 \%$ are essentially pure albite (Maynard, 1984). 


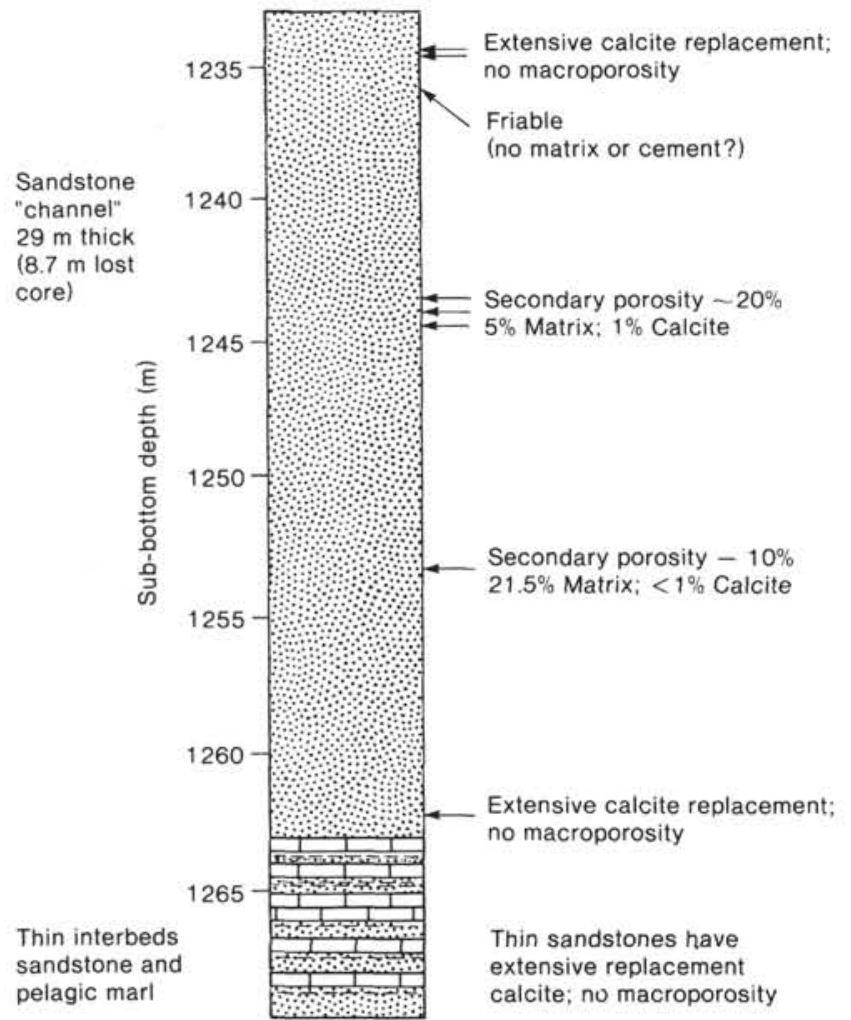

Figure 2. Diagrammatic representation of thick sandstone near the top of the Lower Cretaceous turbidite section in Hole 603B. Arrows indicate locations of samples studied.

Selective removal of the more calcic plagioclase during diagenesis, without modifying the composition of the remnant plagioclase, would increase the percentages of the remaining modal classes. A proportional recalculation of these classes produces the lower histogram of Figure 5. This histogram also has $\mathrm{An}_{0-5}$ as the primary class $(37 \%)$, which compares favorably with the upper histogram (Fig. 5) for the Lower Cretaceous sandstones. This suggests that provenance and selective removal of calcic plagioclase is a possible explanation for the abundance of albitic plagioclase in the Lower Cretaceous sandstones. Albitization may play a role, but more microprobe data over a considerable depth range would be needed to substantiate the process.

\section{Diagenesis}

Most of the sandstone samples are argillaceous, with essentially no macroporosity. Authigenic components in these samples are restricted to replacements because of the lack of open pores needed for authigenic precipitation. Pyrite occurs ubiquitously as a replacement of argillaceous material and within chambers of skeletal grains. Trace amounts of titanium minerals (ilmenite-leucoxene) are associated with volcanic lithic fragments. The most significant authigenic event is the replacement of argillaceous matrix and framework grains by medium crystalline $(\sim 75 \mu \mathrm{m})$ calcite (Fig. 6). Based on 25 microprobe spot analyses, the calcite cement in Sample 603B$46-1,55 \mathrm{~cm}$ is ferroan, having an average composition (mol\%) of $\mathrm{Ca}_{94.06} \mathrm{Mg}_{0.75} \mathrm{Fe}_{2.34} \mathrm{Mn}_{2.85}$. Zonal variation of iron and/or manganese was not detected in the cal-
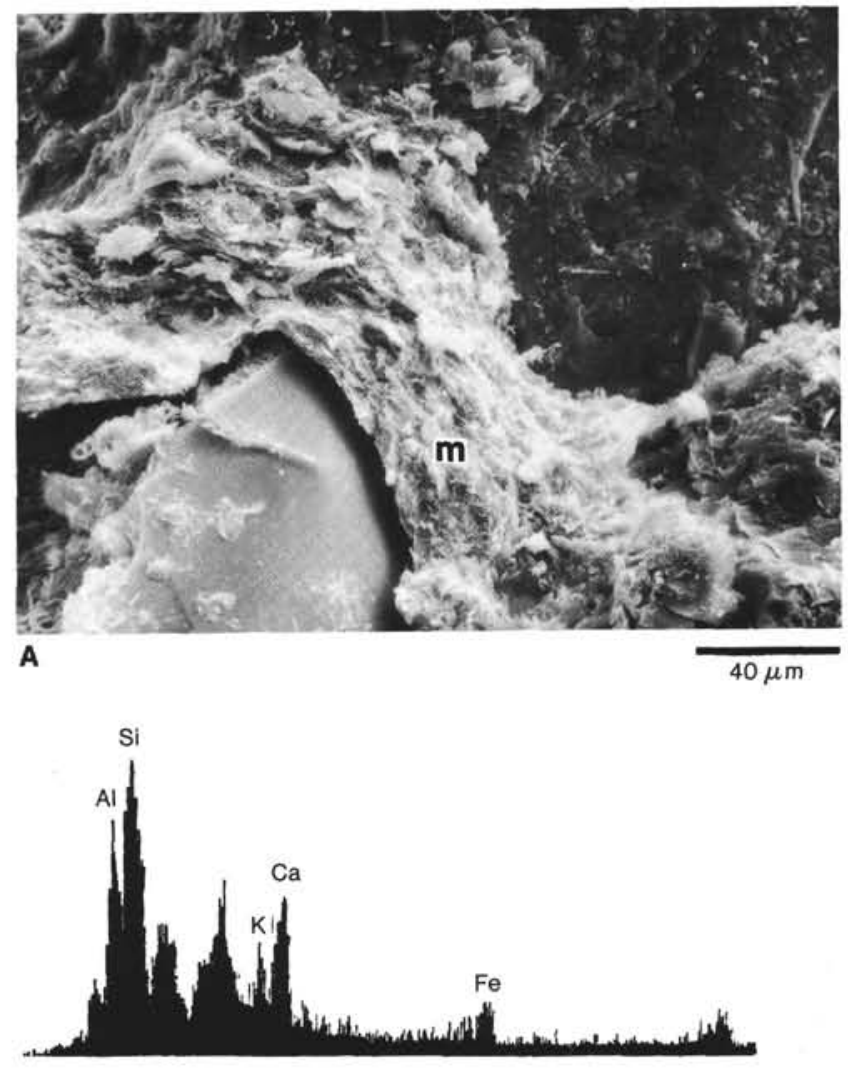

B

Figure 3. A. Scanning electron micrograph showing detrital matrix (m). B. Energy-dispersive X-ray spectrum for a spot analysis at " $\mathrm{m}$ " suggests a mixed-layer illite/smectite clay. There is a suggestion of a small magnesium peak at the left margin, which may indicate the presence of chlorite. Unlabeled peaks correspond to elements in the conductive coating. Sample 603B-62-2, 47-50 cm.

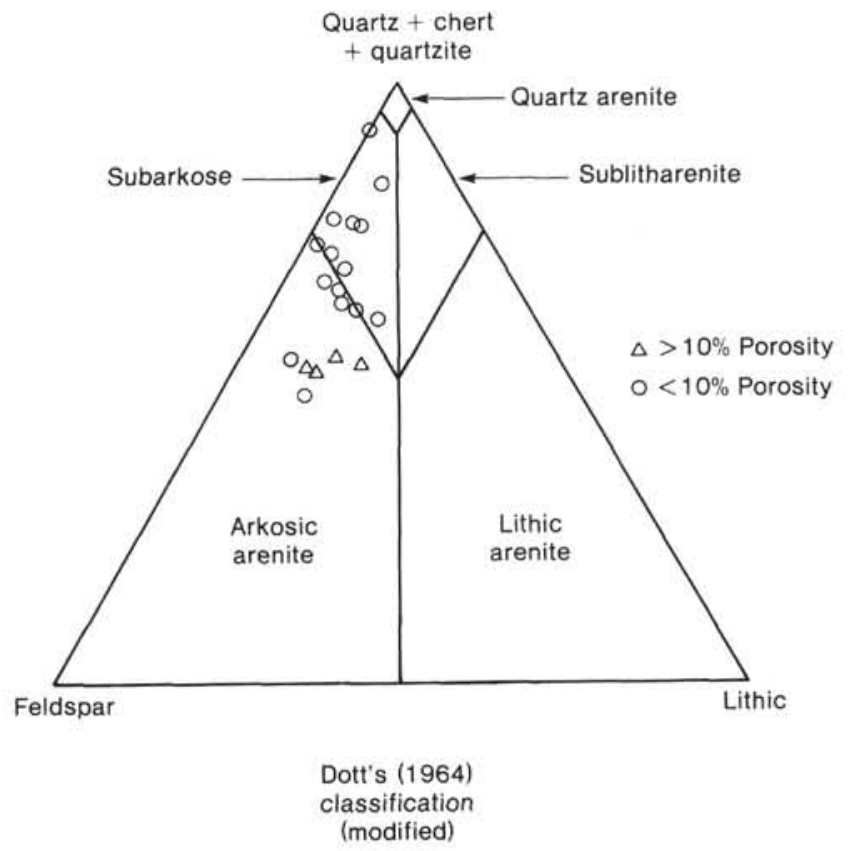

Figure 4. Classification of sandstones in the Lower Cretaceous submarine fan complex by thin-section modal analysis. Sandstones represent arkoses and subarkoses. 

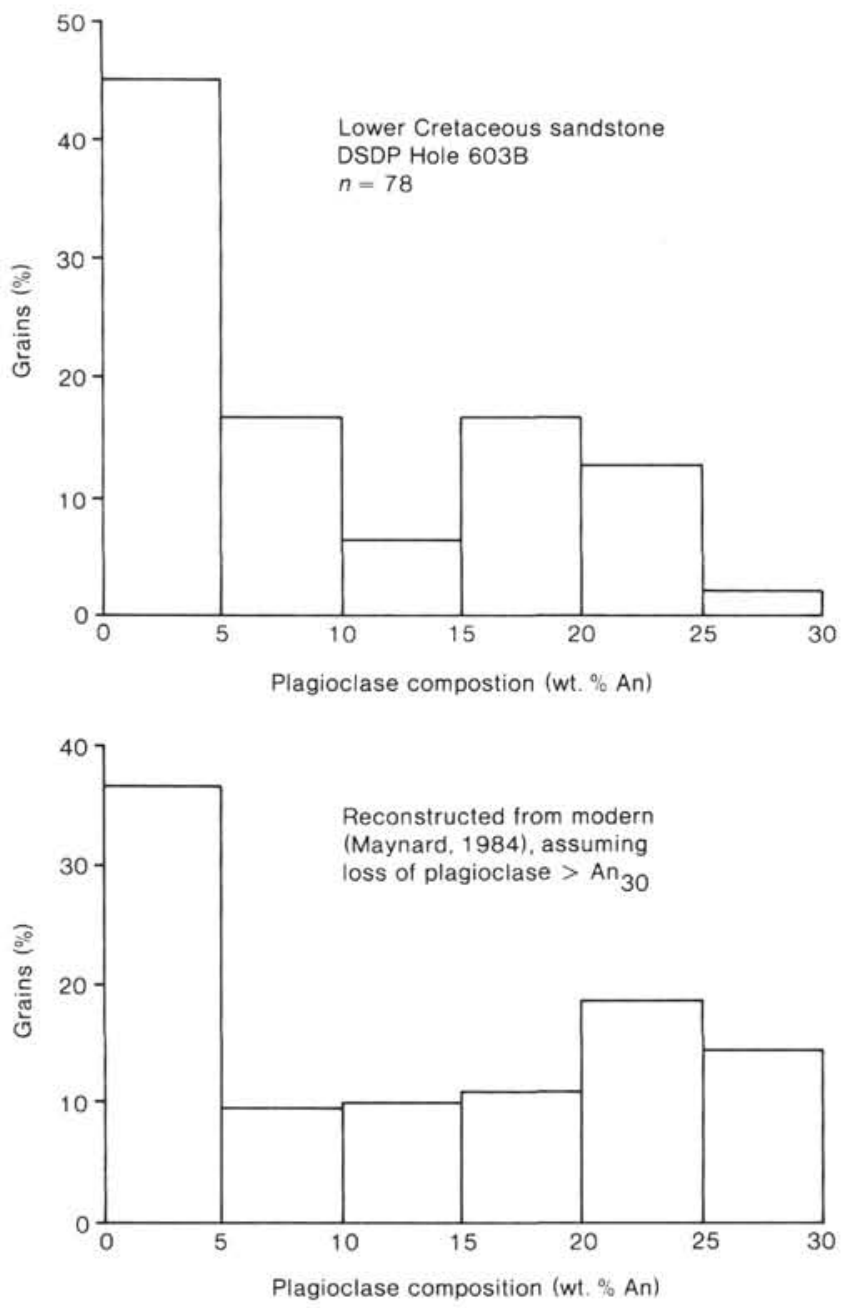

Figure 5. The upper histogram depicts plagioclase composition in Lower Cretaceous sandstones, based on microprobe analyses in three samples. The lower histogram is based on a study of plagioclase composition in modern sediments (Maynard, 1984). For this histogram, plagioclase more calcic than $\mathrm{An}_{30}$ was assumed to be lost by diagenesis and the remaining plagioclase was redistributed proportionately among the remaining classes. In both histograms, albitic material constitutes the primary mode, which suggests that albitization need not play a major role in explaining the compositional distribution of the Lower Cretaceous sandstones.

cite. The replacement origin for the ferroan calcite is supported by its anhedral crystal morphology (loaf-shaped) and the lack of enfacial junctions at triple contact points (Bathurst, 1971). In some samples, the replacement is essentially complete, but in other samples the replacement carbonate is less than $1 \mathrm{vol} . \%$. Within a thin section, a transition from unreplaced to advanced replacement of the matrix by calcite sometimes occurs (Sample 603B-68-2, 92-95 cm). The scanning election microscope reveals remnant clay within and among the replacement ferroan calcite crystals (Fig. 7A). Energy-dispersive X-ray (EDX) substantiates the ferroan calcite identification (Fig. 7B) and indicates that the entrapped mixed-layer illite/smectite is also iron-bearing (Fig. 7C). The iron in the smectite may be the source of the iron in the replacement calcite, but the current database is inadequate to

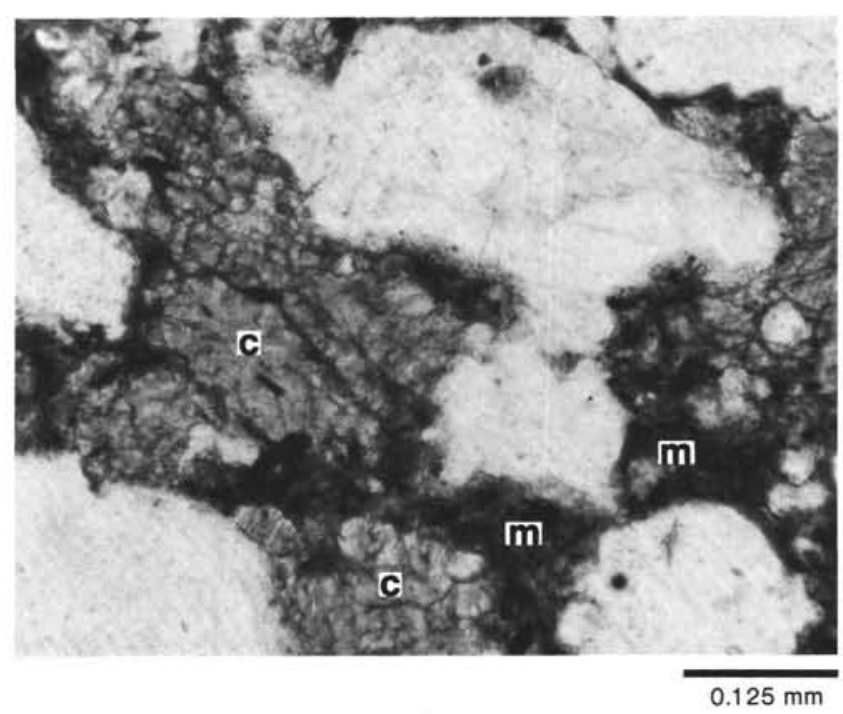

Figure 6. Transmitted-light photomicrograph showing ferroan calcite (c) replacing darker matrix $(\mathrm{m})$ in which light-colored sand grains are embedded. Sample 603B-62-3, 47-50 cm.

substantiate this hypothesis. Ferroan calcite also replaces lithic fragments, feldspars, and quartz (Fig. 8).

Excluding the friable sand, macroporosity is predominantly secondary and has formed from the dissolution of ferroan calcite replacements (Fig. 9). This has produced oversized, moldic, and intragranular pores, and cockscomb textures in feldspars, all of which have been cited as evidence for the presence of secondary porosity (Schmidt and McDonald, 1979). Patches of unreplaced argillaceous matrix are common in porous sandstones when viewed with a scanning electron microscope (Fig. 10A) and appear as brownish material in thin section. Silicate framework grains can dissolve directly without a carbonate replacement stage (Surdam et al., 1984), but the textural evidence suggests that replacement of silicate grains is so common that intragranular-moldic porosity probably has formed from dissolution of ferroan calcite (Fig. 10B). Ferromagnesian heavy minerals show evidence of dissolution. Lithic fragments are often microporous, but rarely contain secondary macropores.

The core descriptions (see Site 603 chapter, this volume) reported that core from the interval 1234.4-1263.4 m sub-bottom was soft, soupy, or disturbed and in places unconsolidated. Approximately $22.5 \mathrm{~m}$ of this cored interval was not recovered. Our evaluation of the porous interval is based on seven samples, including one sample of friable sand (Fig. 2). Judging by the samples studied, this is the only interval with significant macroporosity $(>10 \%)$. The other sandstone samples have, at most, a few percent porosity, but typically have $<1$ vol. $\%$ macroporosity.

Secondary porosity development is partly dependent on the interplay of two processes: (1) the amount of ferroan calcite that replaced the matrix and framework grains; and (2) the amount of ferroan calcite dissolved to create secondary porosity. The following discussion of selected samples will illustrate the interrelationship. 


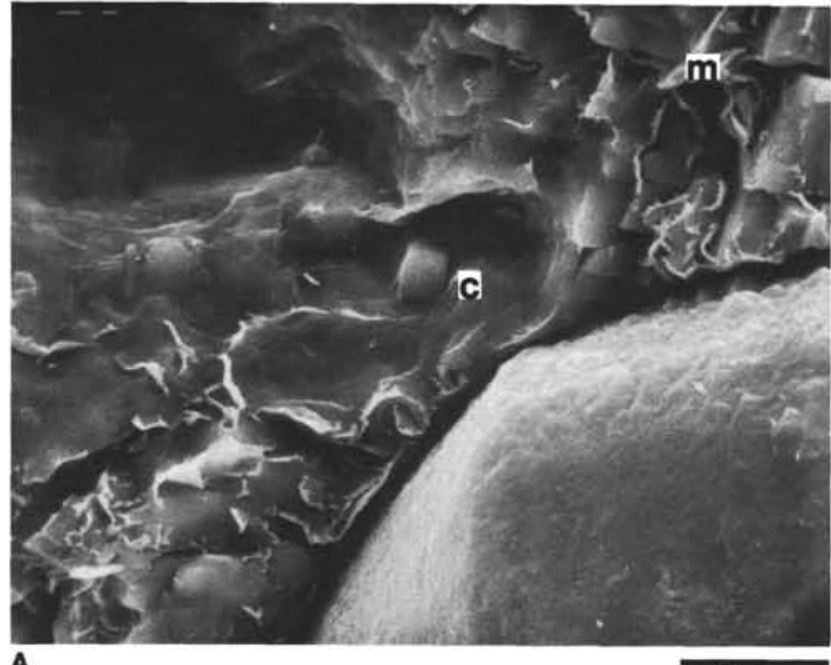

A

$10 \mu \mathrm{m}$

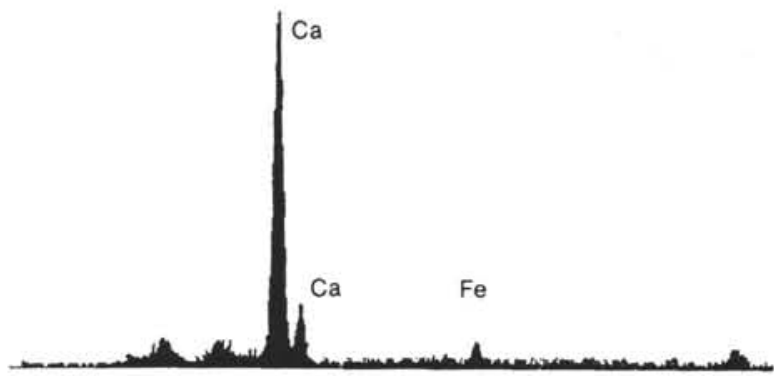

B

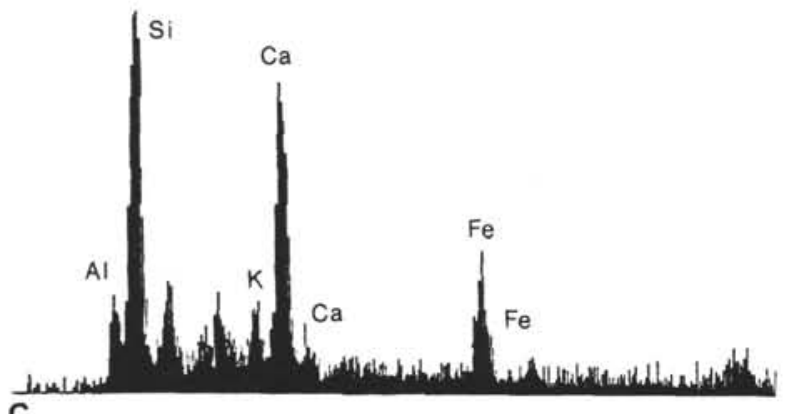

C

Figure 7. A. Scanning electron micrograph showing sand grain in lower right bound by ferroan calcite (c) containing wisps of unreplaced clay matrix (m). B. EDX spectrum for calcite substantiates the presence of iron. Unlabeled peaks are $\mathrm{Au}$ and $\mathrm{Pd}$ contained in the evaporative coating. C. EDX pattern for matrix shown in A suggests an iron-bearing mixed-layer illite/smectite; Sample 603B-66-4, $45-49 \mathrm{~cm}$.

Sample 603B $48-1,47-51 \mathrm{~cm}(\sim 1253.3 \mathrm{~m}$ sub-bottom), has 21.5 vol. $\%$ argillaceous matrix, $<1$ vol. $\%$ ferroan calcite and $10 \mathrm{vol} . \%$ macroporosity. Calcite replacement of matrix was not extensive, but essentially all of the replacement calcite was dissolved to create secondary porosity. In contrast, Sample 603B-46-1, $60 \mathrm{~cm}$ (1234.2 m sub-bottom) has essentially no matrix, 43.5 vol. \% ferroan calcite, and no macroporosity. Although calcite replacement is extensive, the calcite was not dissolved to create secondary porosity. If the ferroan calcite was removed from this sample, it would yield a sample analogous to the friable material from 603B-46-2,

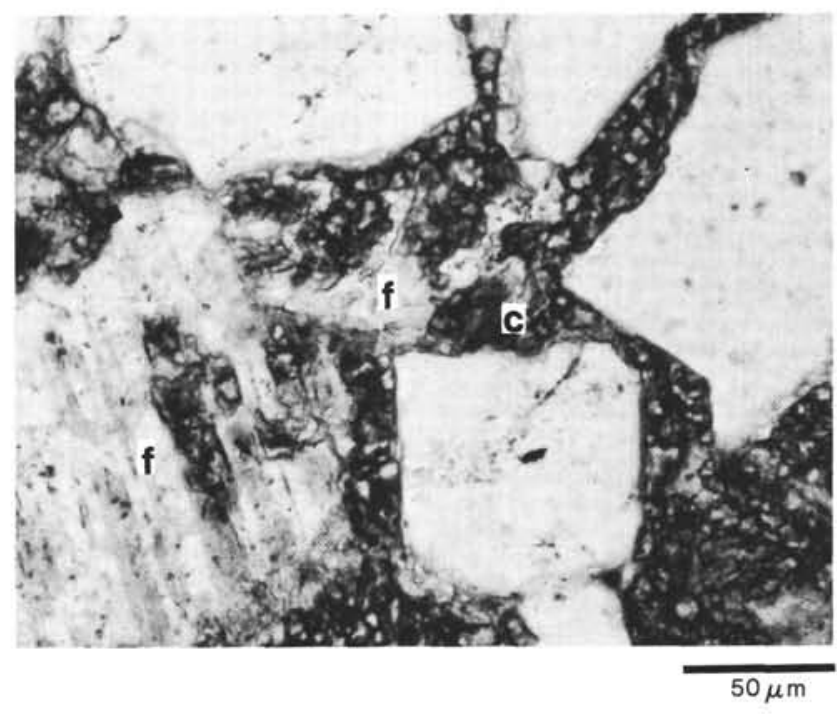

Figure 8. Transmitted-light photomicrograph of ferroan calcite (c) replacing feldspar grains (f). Ferroan calcite has also replaced the argillaceous matrix. Sample 603B-68-2, 92-95 cm.

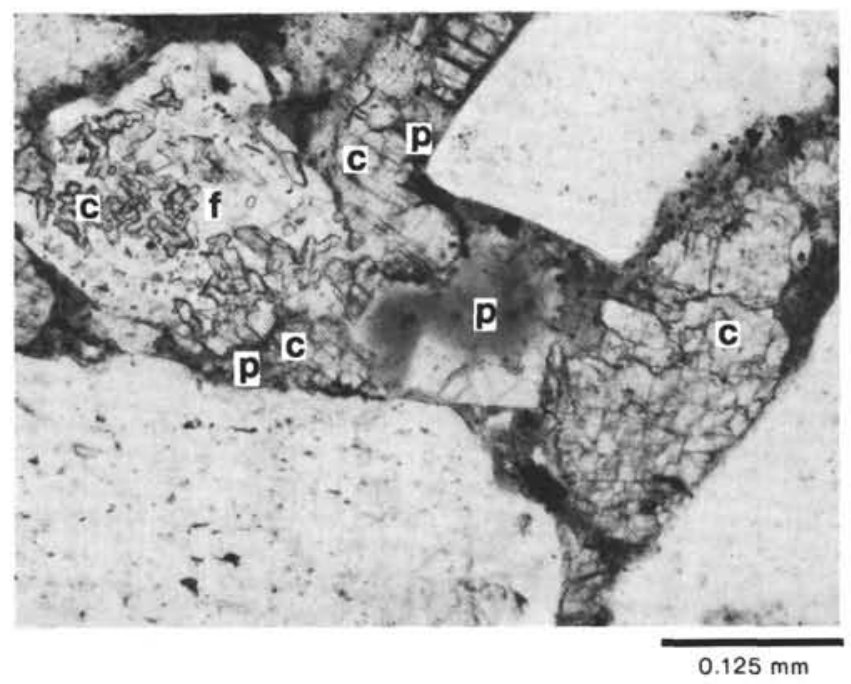

Figure 9. Transmitted-light photomicrograph of secondary porosity (p) resulting from partial dissolution of ferroan calcite (c), which has extensively replaced matrix. Remnant matrix appears as dark patches. A plagioclase feldspar (f) grain is partially replaced by calcite. Sample 603B-62-2, 47-50 cm.

$30-32 \mathrm{~cm}(\sim 1235.41 \mathrm{~m}$ sub-bottom), which has essentially no matrix, a trace of ferroan calcite, and a porosity of perhaps $35-40 \%$. This presents a dilemma. We have interpreted the friable sand in Sample 603B-46-2, $30-32 \mathrm{~cm}$ as having only patchy calcite cement that was later dissolved. It would however, be possible to produce the same result through total replacement of matrix by calcite, followed by complete dissolution of this calcite. Other porous samples typically have about $5 \mathrm{vol} . \% \mathrm{ma}-$ trix, 1 vol. $\%$ ferroan calcite and about 20 vol. $\%$ macroporosity. Calcite replacement of the matrix was not complete in these intervals, but essentially all of the calcite was dissolved. The exact relationship of noncementation 

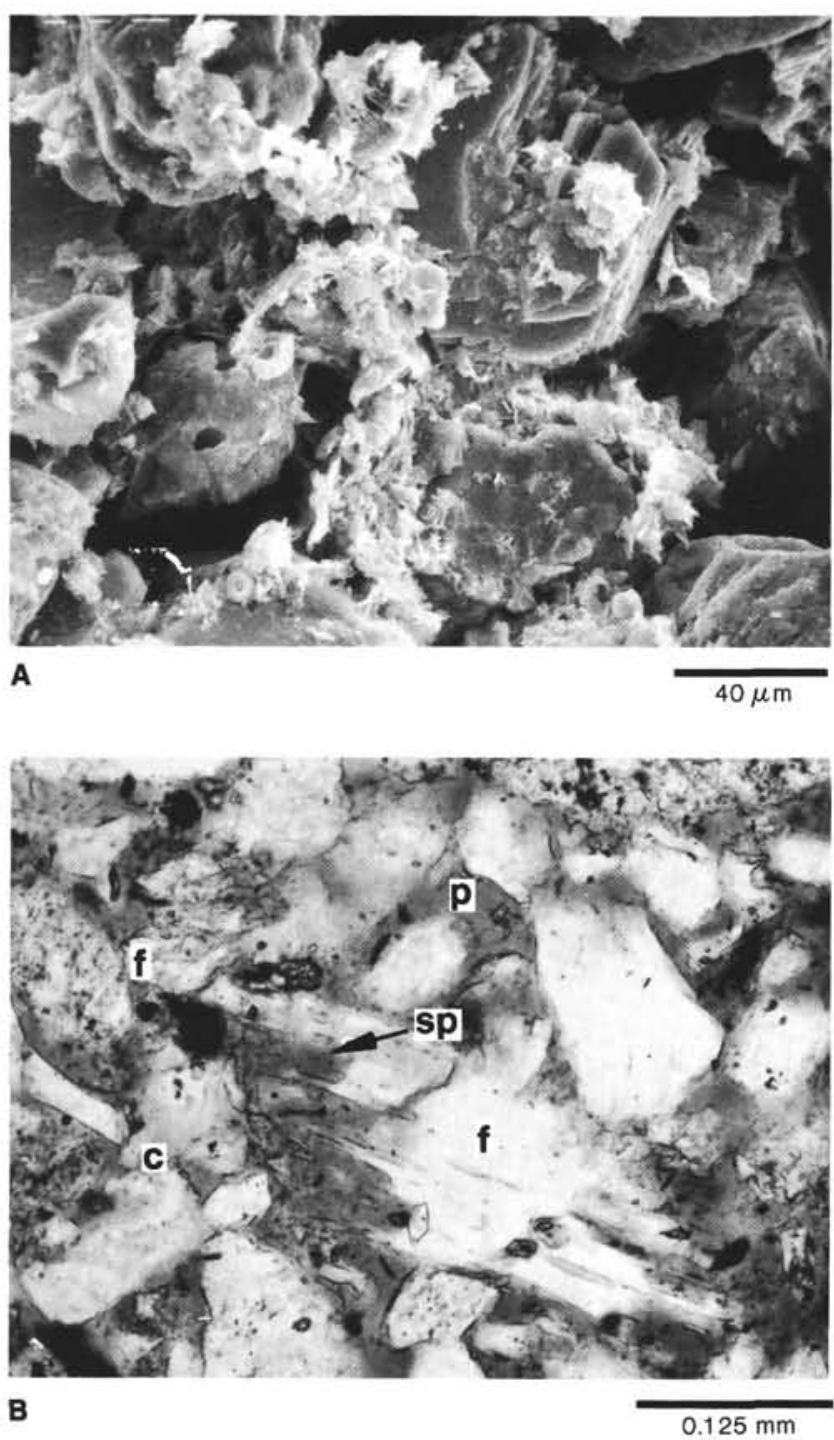

Figure 10. A. Scanning electron micrograph of patches of remnant matrix following replacement by and dissolution of ferroan calcite; Sample 603B-47-1, 69-73 cm. B. Dissolution of feldspar or ferroan calcite that replaced feldspar ( $f$ ) has produced a cockscomb structure and secondary porosity (sp). Intergranular porosity (p) is also secondary and formed from dissolution of ferroan calcite that replaced matrix. Sample 603B-47-1, 35-39 cm.

to complete dissolution of calcite cement in the friable sand remains problematical. However, there is no doubt about the importance of calcite dissolution in creating macroporosity in other associated samples.

Siderite occurs as sparse $25-35 \mu \mathrm{m}$ "wheat"-shaped rhombohedra replacing ferroan calcite in a few samples. Siderite also occurs in the form of silt- and sand-sized framework grains, probably as a complete replacement of an unknown precursor. These grains are composed of a mosaic of crystals approximately $15 \mu \mathrm{m}$ in diameter. The siderite grains occur in fine-grained laminae along with concentrations of opaques and micas. It is possible that these replacement siderite grains were derived from the shelf and transported to the continental rise. We believe that these siderite grains could not have survived a subaerial weathering cycle so must have originated in the marine environment. Siderite also occurs interspersed among the cleavage flakes of some muscovite grains. Although this is evidence of an authigenic origin, it does not necessarily mean the siderite formed in situ.

Rare ankerite rhombohedra occur as "a replacement of ferroan calcite. These crystals are too uncommon to be paragenetically related to siderite.

Porous samples have authigenic minerals that are not present in matrix-rich or calcite-rich samples. The most common is secondary feldspar, which occurs as overgrowths on the surface of detrital grains (Fig. 11A) and less commonly, overgrowths on the remnants of partly dissolved feldspar (Fig. 11B). The authigenic feldspar has essentially pure sodium or potassium end-member compositions, based on a microprobe survey. This is expected from the work of Kastner and Siever (1979). In
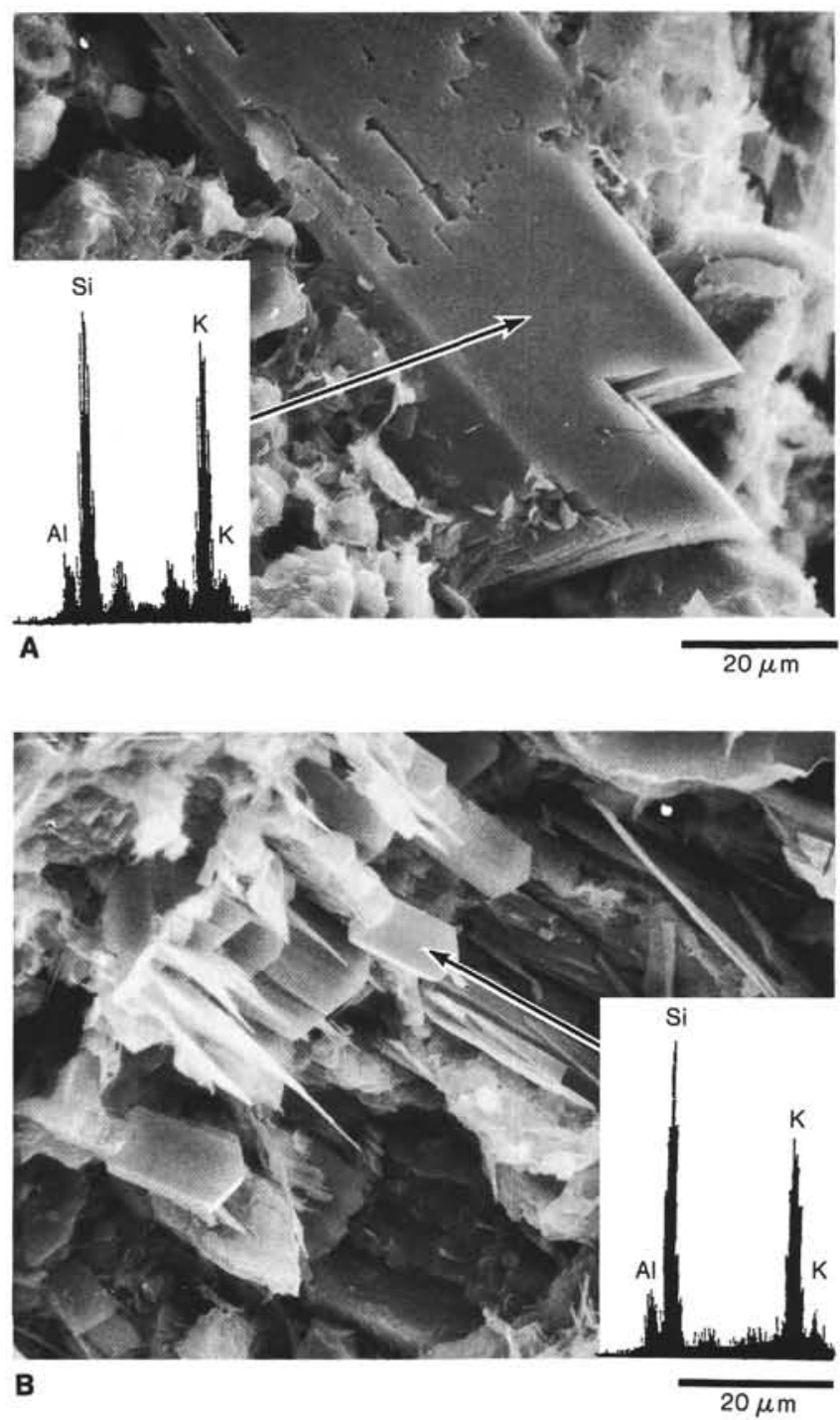

Figure 11. Scanning electron micrographs. A. K-feldspar overgrowth; Sample 603B-47-1, 69-73 cm. B. Tabular authigenic K-feldspar crystals associated with a partly dissolved feldspar. These minute crystals appear to have a common orientation, suggesting growth on remnant feldspar; Sample 603B-47-1, 35-39 cm. Energy-dispersive spectra show the authigenic feldspar to be potassic. 
thin section, and when viewed with the SEM, small, euhedral K-feldspar crystals are seen associated with partly dissolved feldspar. These crystals are not always aligned with the remnant feldspar and may have nucleated without a template.

Other authigenic growths include sparse quartz overgrowths on framework grains and modification of clay minerals in the remnant matrix. The remnant matrix in sandstones of Subunit VA often takes on an authigenic character, with a more open packing and delicate wisps of clay (Fig. 12) forming as regenerated or neoformed clay minerals. Nannofossils occur in this material. An energy-dispersive X-ray spot analysis for an authigenic fiber of clay indicates the presence of calcium and potassium, suggesting a mixed-layer illite/smectite (Fig. 12).

A minor amount of zeolite was noted in several thin sections, associated with shaly laminae or present as cement in very fine grained sandstone. Based on the detection of potassium by EDX, we believe this is phillipsite, although we were unsuccessful in confirming this by $\mathrm{X}$-ray diffraction (XRD). This zeolite occurs as radiating crystals with individual crystals up to $120 \mu \mathrm{m}$ in length.

Tabular crystals $10-15 \mu \mathrm{m}$ long commonly are adhered to sand grains in the friable sample from 603B-46-2, 30$32 \mathrm{~cm}(\sim 1235.4 \mathrm{~m}$ sub-bottom). EDX indicates the presence of calcium and sulfur in these crystals, suggesting a
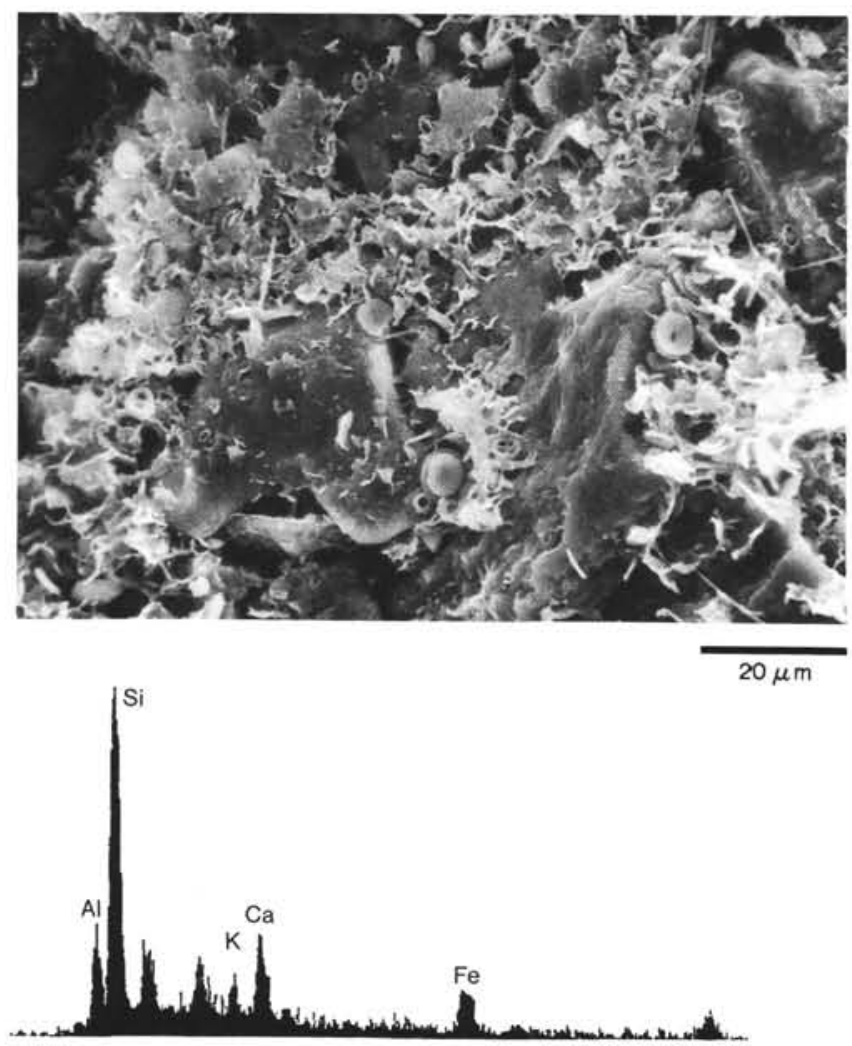

Figure 12. Scanning electron micrograph showing authigenic character imposed on matrix remaining after replacement and dissolution of ferroan calcite. Note nannofossils associated with the remnant matrix. Energy-dispersive X-ray spectrum shows presence of calcium and potassium suggestive of a mixed-layer illite/smectite. Sample 603B 57-4, 50-56 cm. sulfate such as anhydrite or gypsum. These crystals have been tentatively identified as gypsum by XRD, although the crystal morphology appears to be more orthorhombic than monoclinic. Formation of the gypsum(?) is believed to be due to desiccation during core storage, a process discussed by Briskin and Schreiber (1978).

\section{Fine Grained Rocks}

\section{Claystones}

The claystones probably represent the very fine components ("tails") of turbidity currents. X-ray diffractometry of the clay minerals ( $<2 \mu \mathrm{m}$ fraction) was made by J. C. Hoffman for one sample (603B-56-1, 123-126 cm) of claystone. The dominant clay mineral is a mixed-layer, randomly interstratified illite/smectite with approximately $80 \%$ smectite layers (Fig. 13). The composition of this mixed-layer clay was determined following the technique of Reynolds and Hower (1970). Illite, kaolinite, and chlorite also occur in the claystone. Very fine flakes of muscovite are visible in thin section. X-ray diffractometry of the whole rock indicates the presence of quartz, feldspar, and pyrite.

\section{Pelagic Limestones}

XRD indicates that calcite constitutes a significant proportion of the marls and marly limestones that comprise the pelagic facies. The clay mineral assemblage is the same as in the claystones. Other minerals include quartz and feldspar. In thin section, trace amounts of phosphatic material of organic origin and muscovite are visible.

Only the more robust nannofossils are present in the pelagic limestones from Subunit VA and some of these are partly dissolved (Fig. 14). Delicate forms, such as holococcoliths, are largely absent (Covington and Wise, this volume).

In some thin sections, ferroan calcite in the form of ovoid to elliptical bodies up to $35 \mu \mathrm{m}$ long occurs. Individual ferroan calcite crystals that compose the bodies range from 6-30 $\mu \mathrm{m}$. These bodies probably represent calcite-replaced radiolaria (R. W. Scott, personal communication, 1985).

\section{STABLE ISOTOPE GEOCHEMISTRY}

The small size of the skeletal and authigenic carbonate cement components $(<200 \mu \mathrm{m})$ made it impossible to physically separate and analyze them individually. Thus the stable isotopic composition results reported are wholerock carbonate values (Fig. 15 and Table 1). Calcite skeletal material and iron-rich calcite cement are the major carbonate components in the samples analyzed. Ankerite and siderite are volumetrically insignificant. These minor carbonate components are believed not to contribute a distinct stable isotopic signal to the whole-rock analyses.

The stable isotopic analyses were undertaken in order to address the following questions. Is there a significant $\delta^{18} \mathrm{O}$ shift away from normal marine biogenic values for the authigenic calcite? Is this shift a result of precipita- 

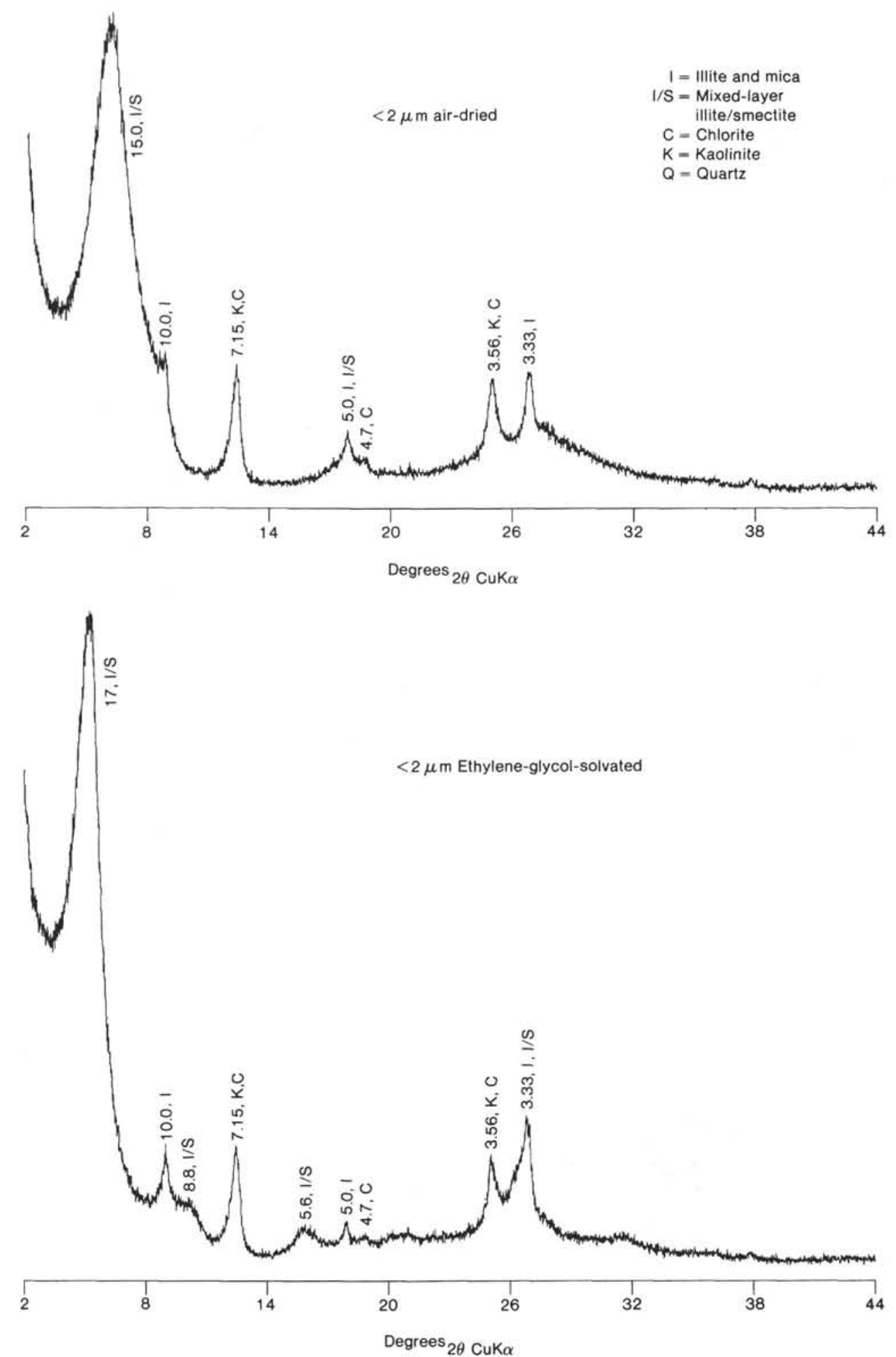

Figure 13. X-ray diffractograms for air-dried and glycol-treated $<2 \mu \mathrm{m}$ fraction in claystone. Mixed-layer interstratified illite/smectite with $80 \%$ expandable layers is the dominant clay mineral. Sample 603B-56-1, $123-126 \mathrm{~cm}$.

tion during burial? If so, can the approximate temperature of precipitation be determined? Do the $\delta^{13} \mathrm{C}$ compositions indicate that organic diagenetic processes significantly influence carbonate replacement?

The oxygen and carbon stable isotope composition of the carbonate components contained in the sandstone and pelagic limestone samples (Fig. 15) shows wide range. This variability is directly related to the diagenetic modification of the primary stable isotopic signature of the sediment. This primary signal is largely controlled by the biogenic carbonate component in the sediment, mostly nannoplankton skeletal debris. A compositional range 


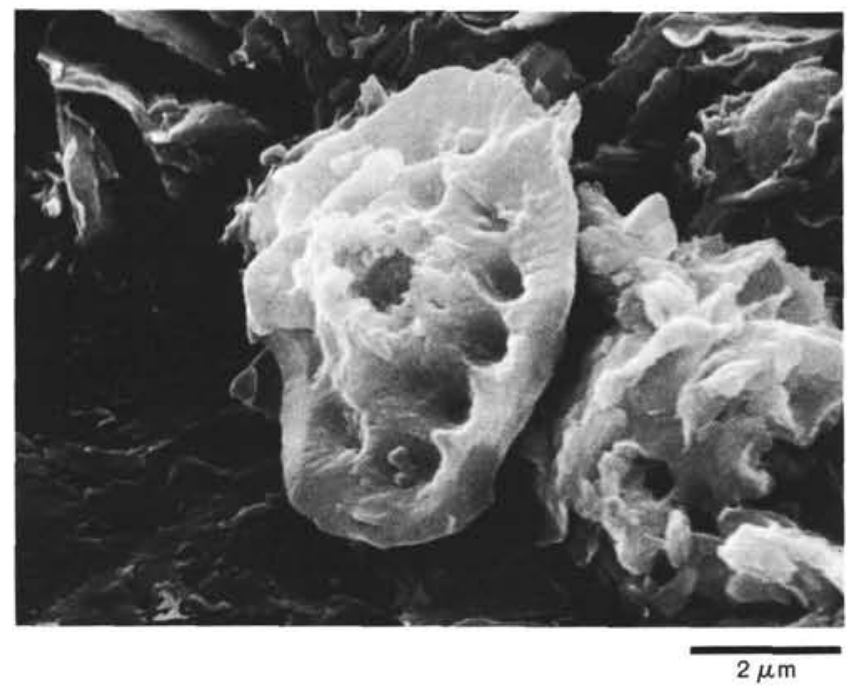

Figure 14. Scanning electron micrograph of partially dissolved coccolith in marl; Sample 603B-50-1, 96-104 cm.

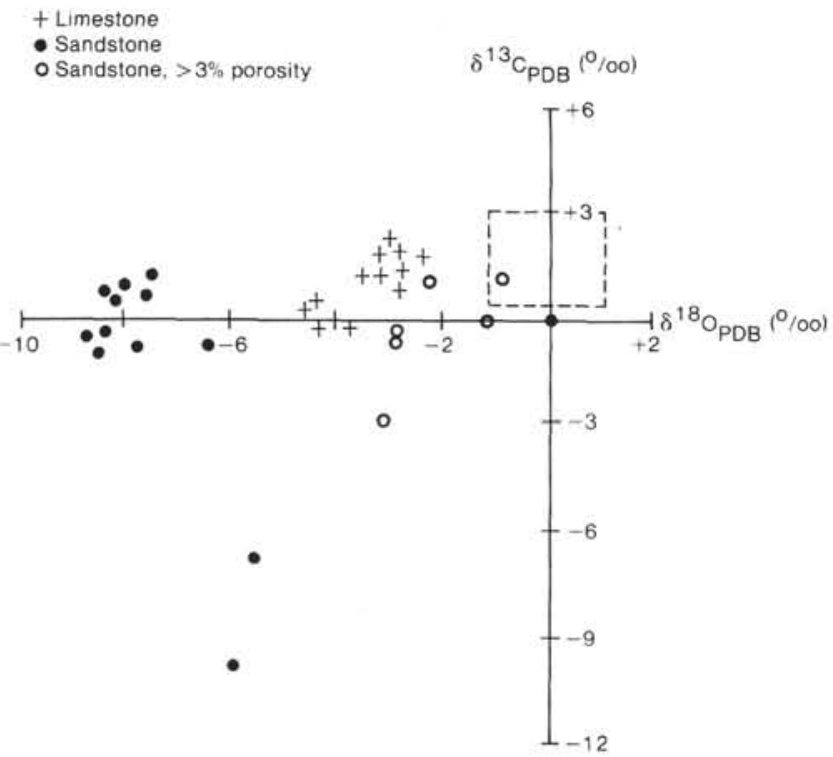

Figure 15. Bivariate plot of $\delta^{18} \mathrm{O}$ and $\delta^{13} \mathrm{C}$ compositions of the calcite contained in sandstones and pelagic limestones. The calcite contained in the sandstones apparently occurs in two trends. Samples in the trend containing porous sandstones are from the same stratigraphic interval. The area enclosed by the dashed line represents the expected stable isotopic compositional range of nannoplankton material at the time of deposition (Stout, 1985).

of -1 to +1 for the oxygen stable isotope composition and of +0.5 to +3.0 for the carbon stable isotope composition can be considered the primary signal range (Stout, 1985). Diagenetic alteration of the carbonate components with increasing temperature will tend to shift the $\delta^{18} \mathrm{O}$ signature toward more negative values. The magnitude of this depletion trend will be dependent on the changes in the oxygen stable isotope composition of the interstitial water. This trend has been commonly documented in other DSDP studies (Garrison, 1981). The $\delta^{18} \mathrm{O}$ compositional range of -2.5 to -4.5 for the limestones analyzed indicates that a $2-5 \%$ negative diagenetic shift has occurred during burial diagenesis. We discount the
Table 1. Stable isotopic data of carbonate fraction from Hole 603B.

\begin{tabular}{|c|c|c|c|c|}
\hline \multirow{2}{*}{$\begin{array}{c}\text { Core-Section } \\
\text { (interval in } \mathrm{cm} \text { ) }\end{array}$} & \multicolumn{2}{|c|}{$\begin{array}{l}\text { Importance of } \\
\text { carbonate } \\
\text { components }(\%)\end{array}$} & \multicolumn{2}{|c|}{$\begin{array}{c}\text { Isotopic values } \\
\text { (\%o PDB) }\end{array}$} \\
\hline & Calcite & Siderite & ${ }_{\delta^{13}}^{13}$ & $\delta^{18} \mathrm{O}$ \\
\hline $46-1,55$ & 20 & & -6.9 & -5.6 \\
\hline $46-1,60$ & 30 & & -10.1 & -5.9 \\
\hline $46-2,30-32$ & $<5$ & tr & -0.8 & -3.0 \\
\hline $47-1,35-39$ & $<5$ & & -3.0 & -3.1 \\
\hline $47-1,69-73$ & $<5$ & & -0.1 & -1.3 \\
\hline $47-1,54-66$ & $<5$ & $\mathrm{tr}$ & -0.4 & -3.0 \\
\hline $48-1,47-51$ & $<5$ & & +0.7 & -0.8 \\
\hline $50-1,96-104$ & 25 & & +0.6 & -3.0 \\
\hline $51-1,16-23$ & 5 & & +1.2 & -2.6 \\
\hline $51-3,88-92$ & 20 & & +1.0 & -3.3 \\
\hline $53-1,41-43$ & 15 & & -0.6 & -8.4 \\
\hline $53-1,47-50$ & 15 & & -0.8 & -6.3 \\
\hline $53-1,51-55$ & 85 & & -0.3 & -3.7 \\
\hline $55-2,15-20$ & 15 & & +1.4 & -2.4 \\
\hline $55-4,93-95$ & 25 & & +1.7 & -2.6 \\
\hline $57-4,55-56$ & $<5$ & & +1.2 & -2.3 \\
\hline $57-4,61-66$ & 5 & & -0.6 & -8.3 \\
\hline $57-4,69-75$ & 30 & & -0.4 & -8.5 \\
\hline $58-1,61-65$ & 20 & & -0.9 & -7.9 \\
\hline $61-1,86-91$ & 80 & & -0.1 & -4.4 \\
\hline $62-2,50-56$ & 80 & & +0.2 & -4.5 \\
\hline $62-2,56-57$ & 85 & & +0.2 & -4.2 \\
\hline $66-1,7-10$ & $<5$ & & +0.7 & -2.6 \\
\hline $66-1,7-10$ & & $<5$ & -1.7 & -6.7 \\
\hline $66-2,110-113$ & 45 & & +1.4 & -7.4 \\
\hline $66-3,109-114$ & 30 & & +1.1 & -7.5 \\
\hline $66-4,45-49$ & 40 & & +0.2 & -8.3 \\
\hline $66-5,28-33$ & 35 & & +0.6 & -8.4 \\
\hline $66-5,49-54$ & $<5$ & & +1.4 & -3.1 \\
\hline $66-5,49-54$ & & $<5$ & -1.1 & -10.3 \\
\hline $68-2,92-95$ & 25 & & +1.0 & -8.0 \\
\hline $71-4,68-71$ & 5 & tr & +2.0 & -2.8 \\
\hline
\end{tabular}

possibility of meteoric water diagenesis affecting the $\delta^{18} \mathrm{O}$ composition of these sediments, strictly because of their depositional setting.

Using a $-1.0 \%$ (SMOW) estimate for the oxygen stable isotope composition of the Cretaceous ocean water, the approximate calcite cementation temperatures for the sands can be determined. Using the oxygen isotope calcite-water-temperature relationship established by O'Neil et al. (1969), a maximum carbonate precipitation temperature of $62^{\circ} \mathrm{C}$ was determined for a $\delta^{18} \mathrm{O}$ composition of $-9.5 \%$. This temperature is comparable to the present-day temperature range of the sampled interval, $55-60^{\circ} \mathrm{C}$ (based on a geothermal gradient of $4.2^{\circ} \mathrm{C} / 100$ $\mathrm{m}$, determined from temperatures measured in the borehole). A $\delta^{18} \mathrm{O}$ composition of $-6.0 \%$ approximates the most enriched value for the extensively calcite replaced sandstones (Fig. 15) and yields a temperature of $\approx 40^{\circ} \mathrm{C}$.

A calcite replacement temperature range of $40-62^{\circ}$ is valid only if our assumption of a constant $\delta^{18} \mathrm{O}$ composition for the diagenetic water responsible for dissolution-precipitation is correct. Interstitial water will interact (solution-precipitation) with the carbonate, feldspar, and clay components in the sediment at increasing temperatures. This interaction will shift the $\delta^{18} \mathrm{O}$ composition of the water toward a more enriched or positive value. The magnitude of this positive $\delta^{18} \mathrm{O}$ shift is controlled 
by the initial $\delta^{18} \mathrm{O}$ composition of the minerals, effective molar ratio of the oxygen contained in the water relative to the reactive minerals, rate of carbonate recrystallization, and fluid flow. A maximum positive $\delta^{18} \mathrm{O}$ shift of $0 \% 0$ to $+1.3 \%$ was documented for interstitial waters collected at depths of $500 \mathrm{~m}$ sub-bottom from DSDP Sites 572-574, Leg 85 (Stout, 1985). These interstitial waters were associated with biogenically dominated sediments similar to the marls and limestones present in Hole 603B. If a similar $\delta^{18} \mathrm{O}$ enrichment trend is developed in the interstitial water in Hole 603B, the calculated calcite precipitation temperatures would be too low. The alteration of basement basalts to form authigenic clays and/or zeolites can produce pore waters depleted in ${ }^{18} \mathrm{O}$ (Brenneke, 1977). Basement lies at least $250 \mathrm{~m}$ deeper in the section than the base of Hole 603B, so that although the influence of ${ }^{18} \mathrm{O}$-depleted water from the alteration of basement basalts cannot be totally ruled out, it is considered an unlikely possibility. The vast normal marine $\delta^{18} \mathrm{O}$ signal contained in the sediments overlying the basement would rapidly enrich any depleted diagenetic water moving upward. Determination of the $\delta^{18} \mathrm{O}$ composition of the interstitial water at maximum depth from this site would resolve this question. It is important to note that an enrichment trend in the interstitial water will elevate the calculated average calcite replacement temperatures. The oxygen stable isotope composition of the calcite suggests that the bulk of the calcite replacement of the matrix in these sandstones has occurred near present-day depths. This tentative conclusion assumes that past geothermal gradients were not significantly different from the present gradient.

The $\delta^{18} \mathrm{O}$ composition of the total carbonate contained in the sandstones with greater than $3 \%$ visible porosity are significantly more enriched than that contained in the nonporous sandstones (Fig. 15). This $\delta^{18} \mathrm{O}$ difference can be directly related to the variation in the amounts of authigenic and detrital carbonate components. Calcite replacements dominate the total carbonate in the nonporous sands, whereas detrital carbonate is the most important carbonate component in the porous sands. As a result, the whole-rock $\delta^{18} \mathrm{O}$ composition of the porous sandstones is strongly biased toward a more enriched composition. The amount of this enrichment is determined by the amount and type of remnant carbonate skeletal material.

The majority of the carbonate samples analyzed have a marinelike $\delta^{18} \mathrm{O}$ composition, that is, 0 to $+3.1 \%$ (Fig. 15). However, carbon from the alteration of organic material was incorporated into the diagenetically altered calcite component of a small number of sandstone samples. The importance of organically derived carbon in the calcite can be related to the degree of ${ }^{13} \mathrm{C}$ depletion. The more negative the $\delta^{13} \mathrm{C}$ composition, the larger the contribution of organically derived carbon to the calcite. Irwin et al. (1977), and Pisciotto and Mahoney (1981) have discussed the importance of organic oxidation, sulfate reduction, fermentation, and thermocatalytic decarboxylation on carbonate cementation processes. In their studies, the carbon stable isotope composition of the authigenic carbonate was used as a measure of importance of these processes. Oxidation, sulfate reduction, and thermocatalytic reactions of organic material produce ${ }^{13} \mathrm{C}$-depleted carbon in the form of $\mathrm{CO}_{2}$ and $\mathrm{HCO}_{3}^{-}$. Fermentation processes produce ${ }^{13} \mathrm{C}$-enriched carbon in the form of $\mathrm{CO}_{2}$ (Pisciotto and Mahoney, 1981). The negative $\delta^{13} \mathrm{C}$ shift observed in the samples analyzed must be attributed to a minor contribution of carbon from either oxidation, sulfate reduction, or thermocatalytic reactions involving organic components in the sediment. In these sediments, sulfate reduction is considered to be the most important of these processes.

\section{ORGANIC GEOCHEMISTRY}

Total organic carbon content averages $1.55 \mathrm{wt} . \%$ for four dark gray pelagic marls ranging in depth from 1423.94-1442.0 m sub-bottom. The gas chromatography/mass spectrography (GC/MS) and elemental analyses indicate that the type III kerogen associated with these sediments is immature (Fig. 16). Interpretation of the vitrinite reflectance data is less clear. Based on four samples, the vitrinite reflectance $\left(R_{\mathrm{o}}\right)$ is approximately $0.6 \%$, although there is also a substantial reworked population (unshaded) shown on the histograms (Fig. 17). Workers do not agree on the $R_{\mathrm{o}}$ level that coincides with the start of hydrocarbon generation, although generally it is in the 0.5 to $0.7 \%$ range. This is partly a semantic problem. Some workers use the term "generation" but really mean "expulsion," and as Lewan (1985) has shown, the maximum bitumen generation does not coincide with oil expulsion. Vitrinite reflectance measurements appear to be a good index of the magnitude of thermal stress experienced by kerogen. Vitrinite reflectance, however, may not always be a good index of the stage of petrole-

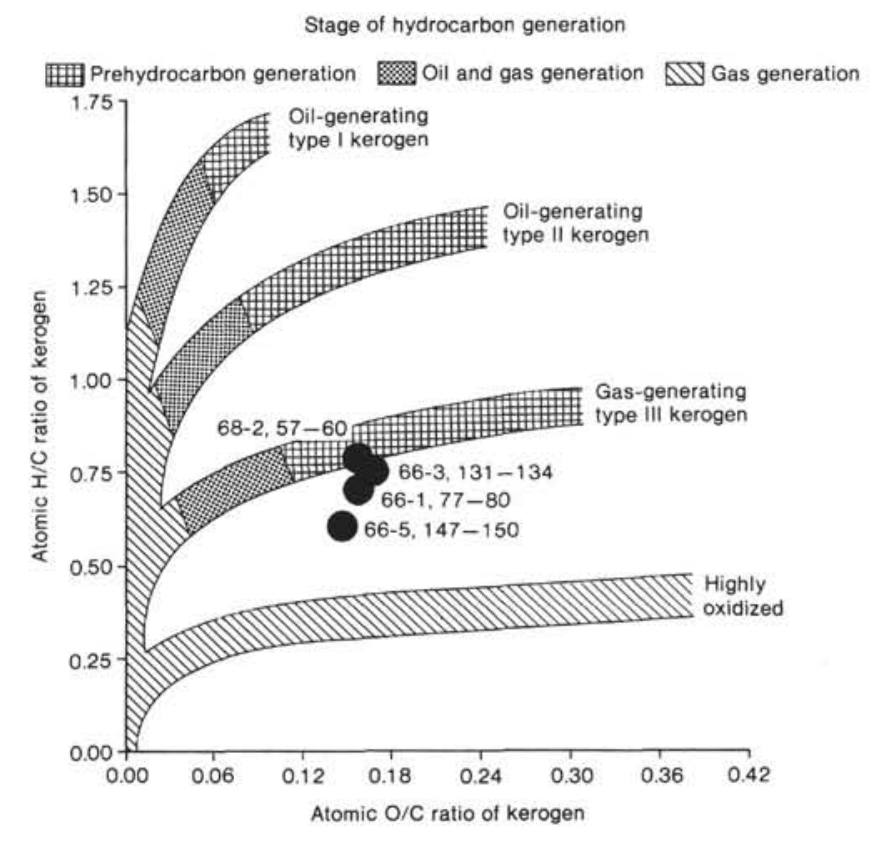

Figure 16. Van Krevelen plot showing results of elemental analyses for four samples of marls and marly limestones from Hole 603B. (See also Fig. 17). 

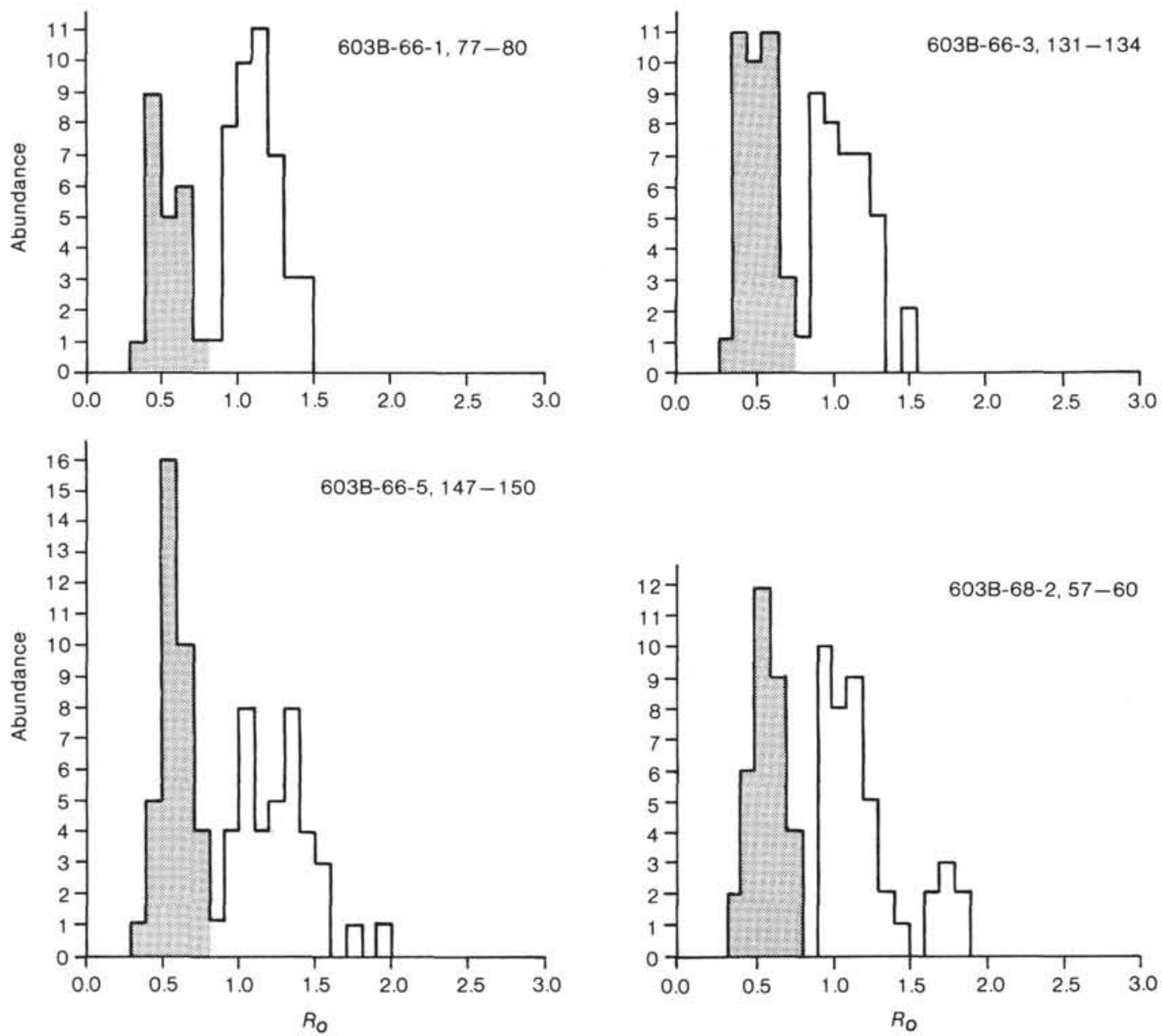

Figure 17. Vitrinite reflectance analysis data for four samples of marls and marly limestones (see also Fig. 16) indicate an average $R_{\mathrm{o}}$ of approximately $0.6 \%$. The nonpatterned part of the histograms is interpreted as the reworked portion of the sample population.

um generation because the kinetics for oil generation are not the same for all kerogens (Lewan, 1985). We believe the kerogen in these sediments has not generated expelled hydrocarbons.

Type III kerogen is more oxygen-rich than type II kerogen (Tissot and Welte, 1978) and therefore capable of generating more organic acids and carbon dioxide to create acidic conditions. Carboxylic acids generated by the thermal maturation of kerogen are preserved as shortchain aliphatic-acid anions in the formation waters between temperatures of about $80-100^{\circ} \mathrm{C}$ (Carothers and Kharaka, 1978). This does not mean that the organic acids formed at these temperatures, but rather that they are preserved today in the $80-100^{\circ} \mathrm{C}$ temperature range. At temperatures below approximately $80^{\circ} \mathrm{C}$, bacteria destroy the aliphatic-acid anions, and at temperatures above approximately $140^{\circ} \mathrm{C}$, these anions are destroyed by thermal decarboxylation (Carothers and Kharaka, 1978). Robin and Rouxhet (1978) show that most of the carboxyl oxygen is lost prior to the generation of hydrocarbons. This suggests that these aliphatic acids may be available to create secondary porosity quite early. On the other hand, carbon dioxide is generated between 50 and $150^{\circ} \mathrm{C}$, with a peak at $100^{\circ} \mathrm{C}$ (Hunt, 1979). If the borehole temperature is correct, then carbon dioxide is not near peak generation.

\section{DISCUSSION}

\section{Calcite Replacement}

Carbonate replacement is volumetrically the most important diagenetic event affecting the sandstone units studied. Ferroan calcite comprises up to $50.4 \%$ of the whole rock. It occurs as a replacement of silicate framework grains and matrix material. Because of its volumetric importance, the origin and timing of this replacement event is of major interest. The petrographic observations and stable oxygen isotope data suggest that calcite replacement is an intermediate diagenetic process, followed by a dissolution event and the precipitation of minor amounts of silicates.

\section{Source of Calcite}

Dissolution of nannoplankton skeletal material is believed to be the primary source for the calcite that replaces the matrix in the sandstones studied. The pre- 
dominant carbonate component in the interbedded marls is nannoplankton skeletal material. Dissolution of even the robust coccolith skeletal forms is evident (Fig. 14). The absence of delicate nannoplankton forms suggests that they may have been removed by dissolution, which for these forms, is initiated in the water column during sedimentation and continues during burial (Wise, 1977). The carbonate skeletal material dissolved in the water column is lost as a potential source for authigenic calcite during burial diagenesis. The amount of calcite lost to the water column versus that dissolved during the burial of these Cretaceous sediments cannot be determined. Previous studies (Morse, 1977, and Wise, 1977) have suggested that loss of carbonate from the sediment into the water column by diffusion or advection after burial is minimal. The abundance of partially dissolved nannoplankton skeletal material in the marl samples analyzed suggests that an adequate source of carbonate for lithification of the marls and replacement of the clay matrix in the sands is present.

\section{Mass Transport}

The precipitation and/or dissolution of mineral components in a sediment during burial diagenesis is dependent not only on chemical equilibrium but also on chemical transport. Ions formed at sites of dissolution must be transported to sites of precipitation and out of the diagenetic system in order to maintain cementation and dissolution processes. Five general chemical transport mechanisms have been used to explain dissolution-precipitation trends in the subsurface. Meteoric water influx and mineralogical dewatering arising from clay transformations are two of these five mechanisms that can be discounted because of the depositional setting and low burial temperatures. The remaining mechanisms, compactional dewatering (unchanneled and channeled), diffusion, and convective fluid flow are evaluated individually.

Because this is a survey study using a limited database, we intend only to discuss the general transport of calcium as a means of delineating the most plausible mass transport mechanism. In subsequent paragraphs, we develop the following scenario regarding the origin of $\mathrm{Ca}^{++}$for replacement calcite. Briefly, calcium derived from pelagic limestones by the dissolution of nannoplankton skeletal material was transported by diffusion into the associated sandstones, where it formed replacement calcite. This process would be most effective for thin sandstone units adjacent to marls. Based on our samples, the thick sandstone unit $(\sim 1234-1263 \mathrm{~m}$ subbottom) is calcitic and tight at the top and base, but friable in the center. This friable sand may represent a turbidite-channel sandstone without matrix that was at one time lightly cemented by calcite. Some of the primary porosity was retained because the transport mechanism was not adequate for moving significant amounts of $\mathrm{Ca}^{++}$through a thick sandstone unit.

We believe that the bulk of the replacement calcite in the sandstone beds was externally derived. This is suggested by the general lack of detrital carbonate components in the sandstones to serve as an internal carbonate source. The high sedimentation rate for these turbidite deposits generally precludes a significant nannoplankton contribution from the water column. A close association between pelagic limestones and the diagenetic calcite in the sandstones suggests a possible source-sink relationship.

The burial diagenesis of nannoplankton-rich sediments to form chalks has been extensively studied (see Schlanger and Douglas, 1974; Wise 1977, for a review). These studies have documented the importance of dissolutiondiffusion-reprecipitation phenomena in chalks. Variability in the stability of the skeletal components contained in the carbonate oozes is the driving mechanism proposed for lithification (Wise, 1977). These differences are thought to be related to variation in mineralogy, minor and trace element content, organic content, ultrastructure, and morphology of tests (Wise, 1977). Observations of selective removal and/or the development of calcite overgrowths on different species and components of nannoplankton skeletal material are common (Adelseck et al., 1973; Roth et al., 1975).

Regardless of the transport mechanism, calcite solubility must be different between the calcareous sediments (source) and the sandstone unit (sink) in order to drive cementation and/or replacement. The calcareous sediments may be more highly soluble, not only because of the variable skeletal stability documented in studies of chalk diagenesis, but also because of the much higher surface-area/volume ratios of this material (Wise, 1977).

Adamson (1976) indicates that in a system of a mixed mass of crystals, the finest-particle-size group determines the solubility. Generally, particle solubility does not increase until particles of less than $0.1 \mu \mathrm{m}$ are encountered (Adamson, 1976). This particle size is well within the range expected from the disaggregation of some coccoliths (Wise, 1977). Between the finer and coarser crystalline coccolith forms (accounting for calcite overgrowths and cementation within the limestone unit) and the adjacent coarser-grained sandstone units, a concentration gradient can be established. Larger crystalline carbonate nucleation grains are likely to concentrate in the sandstone. The replacement of these sandstone units may be self-limiting. The progressive calcite replacement of the matrix in the sandstone units from the exterior to the interior of the bed could significantly affect the rate of later carbonate transport to the interior. As permeability decreases in the sandstones adjacent to the source limestones, interior replacement would be restricted. This restriction is related to the increase in tortuosity and decrease in permeability and the effective cross-sectional area for diffusion and fluid flow in the sand undergoing replacement. Diffusional rates will decrease with increasing tortuosity and lower permeabilities (Berner, 1971 and 1980; Pandey et al., 1974). This self-limiting feedback could help to account for the distribution of replacement carbonate in the Hole 603B sandstone units; thin sand units are extensively replaced with no macroporosity, whereas the thick sand unit is extensively replaced by calcite only on the exterior margins.

Vertical compactional fluid flow (unchanneled) is believed not to be an important mass transport mechanism 
for carbonate replacement in these sandstones. A simple mass transport calculation helps support this conclusion. The following assumptions were made in these calculations:

1. Porosity reductions of $60 \%$ occurred during burial of the carbonate sediments; that is, an initial porosity of $70 \%$ was reduced to $10 \%$ during burial.

2. All of the interstitial fluid was expelled vertically upward.

3. The $\mathrm{Ca}^{++}$concentration in the water was $\approx 0.4 \mathrm{~g} /$ $\mathrm{Kg}$, similar to the concentration reported by Manheim and Sayles (1974) for interstitial waters in Pacific biogenic deposits.

4. All of the $\mathrm{Ca}^{++}$contained in the interstitial water is used to form calcite in the sandstone during its vertical migration.

5. Replacement calcite makes up $10 \%$ by volume of the sandstone.

Approximately $600,000 \mathrm{~cm}^{3}$ of interstitial water containing 6 moles of $\mathrm{Ca}^{++}$would be released from $1 \mathrm{~m}^{3}$ of carbonate sediment during porosity reduction, and 2720 moles of $\mathrm{Ca}^{++}$would be required to form calcite that makes up $10 \mathrm{vol} . \%$ of a $1 \mathrm{~m}^{3}$ sandstone body. Assuming perfect efficiency (i.e., all of the $\mathrm{Ca}^{++}$in solution goes to form calcite), it would require $\approx 450 \mathrm{~m}^{3}$ of carbonate ooze to provide the $\mathrm{Ca}^{++}$for $1 \mathrm{~m}^{3}$ of sandstone, or a 450:1 carbonate ooze/sandstone ratio. If we decrease $\mathrm{Ca}^{++}$transport efficiency (i.e., only a small percentage of the $\mathrm{Ca}^{++}$in solution is utilized for calcite precipitation) to more realistic values of a few percent or less, the required carbonate ooze/sand ratio increases by almost two orders of magnitude, to a value of $45,000 / 1$. The approximate carbonate ooze/sand ratio for the Cretaceous sediments from Hole $603 \mathrm{~B}$ is $\approx 9: 1$, at least three orders of magnitude too small to account for the replacement calcite. Even if one adds the upward movement of interstitial fluids from below the deepest core point (1576 $\mathrm{m}$ sub-bottom) to the underlying basement (1826 m sub-bottom), a total increase of only $250 \mathrm{~m}$ of section, compaction fluid transport of the carbonate is three orders of magnitude too small to explain the diagenetic carbonate.

Can sufficient material be transported by diffusion over short distances of several meters to account for the carbonate replacement in the thin sandstone units? Previous work (Wood and Hewett, 1982) has suggested that diffusional mass transport is effective only at a grain-tograin scale. They suggest that convectional fluid flow dominates mass transport on a larger scale (Wood and Hewett, 1982, 1984). Recent work by Hanor (1984) suggests that diffusional transport of ions over distances of kilometers can help control the vertical chemical variation of formation waters. Leythaeuser et al. (1982) have shown that diffusion can be an effective process for primary migration of gas to form commercial-sized gas fields. Diffusion of $\mathrm{CO}_{2}$ between hydrocarbons and the underlying formation waters in oil reservoirs is thought to be responsible for extensive carbonate cementation in the water-saturated interval of hydrocarbon reservoirs (Rácz, 1971). At this time, the effectiveness of diffusional mass transport for cementation in the subsurface is still uncertain. In order to help answer this question, particularly in reference to the interbedded Cretaceous sandstones and marls of Hole 603B, a simple diffusional model was constructed. This model was designed to test the possible effectiveness of diffusional transport in a marl-sandstone cycle on a meter scale. The marl was viewed as the source of calcium, the sand as the sink for the calcium in the form of calcite replacement or cement. A constant diffusion gradient or steady-state system was assumed to be maintained between the calcium source and sink; that is, dissolution of nannoplankton skeletal material maintained the calcium concentration in the marl and calcite precipitation maintained a lower concentration in the sandstones. The relative concentration difference was established as $20 \mathrm{mg} \mathrm{Ca}^{++} / 1$. This uses a concentration of $400 \mathrm{mg} / \mathrm{l}$ of $\mathrm{Ca}^{++}$in the marls, a reasonable assumption based on Manheim and Sayles (1974), and a concentration of $380 \mathrm{mg} / \mathrm{l}$ of $\mathrm{Ca}^{++}$in the sandstones. The projected $\mathrm{Ca}^{++}$concentration in the sandstones was chosen to reflect a reasonable difference in solubility arising from particle size differences in the $0.1 \mu \mathrm{m}$ and larger size range. Note that the work of Adamson (1976) on particle size controls on solubility did not include carbonate minerals. Our value of a $5 \%$ difference in solubility should be viewed as an estimate.

The application of Fick's diffusion equations for the determination of diffusional fluxes is dependent on the established boundary conditions for the specific case being studied. Variation of these boundary conditions will always change the solution to the diffusion equation (Crank, 1956).

The boundary conditions assumed for the sandstonemarl model are:

1. The contact between the marl and sandstone units can be approximated as a membrane of thickness $(\ell)$.

2. The faces of the membrane are maintained at a constant but different $\mathrm{Ca}^{++}$concentration after steadystate conditions are established; that is, there is a constant concentration gradient.

3. At $t=0$ the concentration in the membrane is equal to the concentration in the sink (sandstone unit).

The determination of the total mass of diffusing substance $\left(Q_{t}\right)$ which has passed through the 1-m-thick marlsandstone membrane in time $(\mathrm{t})$ can be made by using the following equation derived by Crank (1956).

$$
Q_{t}=\frac{D\left(C_{2}-C_{1}\right)}{\ell}\left(t-\frac{\ell^{2}}{6 D}\right) \text { when } t \rightarrow \infty
$$

where:

$$
\begin{aligned}
D & =\text { diffusion coefficient (remains constant) } \\
C_{2} & =\text { relative } \mathrm{Ca}^{++} \text {concentration in marl, } \\
C_{1} & =\text { relative } \mathrm{Ca}^{++} \text {concentration in sandstone, } \\
\ell & =\text { thickness of membrane, } \\
t & =\text { time in seconds. }
\end{aligned}
$$

We will test the effectiveness of diffusional transport to provide $10,800 \mathrm{mg}$ of $\mathrm{Ca}^{++}$per $\mathrm{cm}^{2}$ through a $1-\mathrm{m}-$ thick membrane. This is enough calcium to provide $10 \%$ by volume calcite cement in a 1-m-thick sandstone unit. 
Given that

$$
\begin{aligned}
D & =1 \times 10^{-6} \mathrm{~cm}^{2} / \mathrm{s}(\text { Berner, } 1980), \\
C_{1} & =0.38 \mathrm{mg} \mathrm{Ca}++/ \mathrm{cm}^{3}, \\
C_{2} & =0.40 \mathrm{mg} \mathrm{Ca}++\mathrm{cm}^{3}, \\
\ell & =1 \text { meter, } \\
Q_{t} & =10,800 \mathrm{mg} \mathrm{Ca}{ }^{++} / \mathrm{cm}^{2},
\end{aligned}
$$

it would take approximately $1.7 \mathrm{~m}$.y. for enough $\mathrm{Ca}^{++}$ to pass through a 1-m-thick marl-sandstone contact (membrane) under steady-state conditions to replace (or cement) a 1 -m-thick sandstone unit with 10 vol. \% calcite. This is a reasonable amount of time in light of a 70 Ma minimum age for these sediments. Even if our assumption regarding the $\mathrm{Ca}^{++}$concentration gradient is overoptimistic by an order of magnitude, diffusional transport can account for the cementation pattern. Diffusion in this closely coupled source-sink system $(1 \mathrm{~m})$ with a constantly maintained concentration gradient potentially can be an effective mass transport mechanism over geologic time. Other geological studies have suggested that diffusion can be an important interformational transport mechanism (Füchtbauer, 1972).

Fluid convection can be an important mass transfer process in the subsurface (Peck, 1967). It can theoretically increase mass transfer rates by at least several orders of magnitude over diffusion. This mechanism has recently gained attention as a process that could theoretically account for major mass transfer events (cementation-dissolution) in the subsurface over major distances (Wood and Hewett, 1982, 1984). This process circumvents the traditional constraint on the availability of diagenetic fluids in unidirectional flow models-e.g., compaction fluid drive systems. Land (1984) discusses the advantages of convective fluid flow in reference to the diagenesis of the Frio sandstones of the Texas Gulf Coast. $\mathrm{He}$, however, suggests caution in directly transferring a theoretical model to different subsurface diagenetic systems. The convective fluid flow model proposed by Wood and Hewett (1982 and 1984) has not been documented in subsurface sedimentary systems. This lack of "proof in the rocks" may only reflect inadequacies in the current data base.

The high permeabilities (1-10 darcies) and homogeneity assumed for the theoretical sand unit used in Wood and Hewett's model do not approximate the low permeabilities suggested by the clay matrix and general inhomogeneity of the Cretaceous sediments found in Hole $603 \mathrm{~B}$. These major differences suggest that a thermally driven convectional mass transfer system may be unimportant in these sediments. The model, as put forth by Wood and Hewett (1982), cannot in our opinion be applied to these sediments to demonstrate the importance of convectional mass transfer.

\section{Origin of Secondary Porosity}

Petrographic evidence indicates that iron-rich, replacement calcite in selected samples in the 1234-1263-m sandstone interval has dissolved to form secondary macroporosity. Interpretation of the origin of the porosity is limited by poor core recovery and the fact that too few samples from this interval were examined. Although an exact estimate of the amount of calcite removed from the major sandstone unit cannot be made, petrographic observations suggest that in some samples it was a significant amount (up to $22 \mathrm{vol} . \%$ ).

Why are the thinner sandstone units apparently unaffected by this dissolution event? We believe that part of the thick sandstone unit was not effectively cemented by calcite at the time of dissolution. This may be the result of time and/or mass transport constraints. The clean high-energy channel portion of the sandstone unit at 1234-1263 m sub-bottom would have been more porous and permeable, which would have allowed for the preferential movement of the diagenetic fluids responsible for dissolution. How did these diagenetic fluids enter the porous and permeable sand? Waters from the shales and marls may have moved vertically along microfractures and/or through the development of high pressuregradients across the zones of low permeability.

We can only speculate that compactional waters have been channelized into this sandstone unit, perhaps as the result of early lithification of pelagic limestone and thin sandstone. These units with low permeabilities would tend to deter vertical fluid movement. As a result, the turbidite channel sandstone may serve as the major pathway for updip compactional fluid movement.

The causative agent (or agents) for dissolution cannot be established with the current data. We are, however, confident that meteoric water, because of depositional setting and history, was not responsible for this secondary porosity. The interplay of pelagic carbonates and the sandstone units during lithification suggest that a time-temperature-dependent interaction among the shales, limestones, and sandstones has occurred. Such a relationship has been suggested by Loucks et al. (1984) to account for the distribution of secondary porosity in the Tertiary clastics of the Gulf Coast. The organic matter associated with DSDP Site 603 Lower Cretaceous sediments contains immature type III structured kerogen with a vitrinite reflectance of $R_{\mathrm{o}}=0.6 \%$. The kerogen has not reached the hydrocarbon generation-expulsion stage, but has started to generate prehydrocarbon alteration products such as organic acids (Robin and Rouxhet, 1978).

The key aspect of the development of this secondary porosity is the low temperature at which it has been initiated, $<60^{\circ} \mathrm{C}$. Support for the relatively low temperature comes from the correspondence between present borehole temperatures and estimated temperatures of precipitation of calcite from oxygen stable isotopes. The clay mineralogy suggests that the sedimentary section has not been substantially hotter in the past. Clay in the claystones is predominantly mixed-layer, randomly interstratified illite/smectite with $80 \%$ smectite layers. Based on Hower et al. (1976) this corresponds to a temperature of approximately $57^{\circ} \mathrm{C}$. If the temperature had been higher, the smectite layers would have decreased at the expense of illitic layers until they reached the limit of $20 \%$ smectite, which corresponds to $100^{\circ} \mathrm{C}$ according to a study in the Gulf Coast by Hower et al. (1976). The tem- 
perature suggested is much lower than that proposed by Franks and Forester (1984) for $\mathrm{CO}_{2}$-generated porosity, $\approx 100^{\circ} \mathrm{C}$, and for organic-acid-generated porosity, $>80^{\circ} \mathrm{C}$ (Surdam et al., 1984). We cannot bring these agents up from significantly deeper in the section unless we suggest a basement origin.

Are we seeing the initial phase of secondary porosity formation caused by the introduction of $\mathrm{CO}_{2}$ (Franks and Forester, 1984) and/or organic acids (Surdam et al., 1984) generated from the alteration of associated organic material? Do heat flow or alteration products from the basement trigger the formation of secondary porosity? Or can formation water in the less permeable marls and sandstones be mixing with that in the major sandstone unit, causing dissolution as generally outlined by Runnels (1969)? These questions cannot be answered at this time.

\section{CONCLUSIONS}

A dynamic diagenetic history is recorded in the Lower Cretaceous turbidite sandstones recovered from Hole 603B. Pyrite, siderite, ankerite, feldspar, quartz, zeolite, and calcite have been precipitated. Iron-rich calcite replacement of the detrital clay matrix in the sandstones is volumetrically the most important constructive diagenetic event. The average calcite precipitation temperatures range from $40-62^{\circ} \mathrm{C}$. The source of calcium carbonate is believed to be the dissolution of nannoplankton skeletal material contained in the interbedded deep-water marls and limestones. Transport of the carbonate from the source (marls and limestones) to the site of precipitation in the sandstone units can be accomplished by steady-state diffusion. Unchanneled, compactional fluid flow and thermal convection transport mechanisms are constrained by restrictions on fluid volume, permeabilities, and vertical sediment heterogeneity and are believed to be insignificant.

Secondary macroporosity is well developed in portions of the thick sandstone unit ( $\sim 1234-1263.4 \mathrm{~m}$ sub-bottom). This macroporosity was formed by the dissolution of the iron-rich replacement calcite. The specific agent responsible for dissolution cannot be identified, but meteoric water, organic acids associated with soil development, or surface weathering can be excluded. Channeled, compactional fluid flow through the incompletely cemented turbidite channel axis is a possible answer.

The early diagenetic processes are dominated by mechanical compaction and diffusional transport in a restricted system. The evolution of a restricted diagenetic system from a cementation to a dissolution phase (secondary porosity formation) suggests that the agent of dissolution is internally evolved. If the products of organic diagenesis, such as $\mathrm{CO}_{2}$ and organic acids, are responsible for this dissolution, we must revise early estimates of the effective thermal windows for porosity generation to lower temperatures. These previous estimates suggest that temperatures of $80^{\circ} \mathrm{C}$ or greater are required to generate and initiate the formation of significant secondary porosity.

This study represents a survey of the petrographic and geochemical analyses of a limited number of core sam- ples from the Lower Cretaceous section of Hole 603B. We emphasize that it should be viewed as a basis for future, more detailed studies and as a forum for presenting speculative ideas. We made no attempt to cover all aspects of the diagenesis of these sediments and hope that this survey will stimulate further research.

\section{ACKNOWLEDGMENTS}

We would like to acknowledge the invaluable assistance of Mary Ann Holmes of the University of Nebraska, Jay Muza and Sherwood Wise of Florida State University, and Janet Haggerty of the University of Tulsa in obtaining material and information for this study. The data from microprobe studies and X-ray diffractometry of clay minerals were provided by Tom Fernalld and J. C. Hoffman, respectively. We are grateful to R. E. Larese and M. A. Miller for critiquing this paper, to Amoco Production Company for their support in this study, and to R. C. Surdam and S. Fisher for their helpful and thought-provoking reviews of the manuscript.

\section{REFERENCES}

Adamson, A. W., 1976. Physical Chemistry of Surfaces: New York (John Wiley and Sons).

Adelseck, C. G., Jr., Geehan, G. W., and Roth, P. H., 1973. Experimental evidence for the selective dissolution and overgrowth of calcareous nannofossils during diagenesis. Geol. Soc. Am. Bull., 84: 2755-2762.

Bailey, E. H., and Stevens, R. E., 1960. Selective staining of K-feldspar and plagioclase on rock slabs and thin sections. Am. Min., 45:1020-1025.

Bathurst, R. G. C., 1971. Carbonate Sediments and Their Diagenesis: Amsterdam (Elsevier).

Berner, R. A., 1971. Principles of Chemical Sedimentology: New York (McGraw-Hill).

,1980. Early Diagenesis-A Theoretical Approach: Princeton, NJ (Princeton University Press).

Brenneke, J. C., 1977. A comparison of the stable oxygen and carbon isotope composition of Early Cretaceous and Late Jurassic carbonates from DSDP Sites 105 and 367. In Lancelot, Y., Siebold, E., et al., Init. Repts. DSDP, 41: Washington (U.S. Govt. Printing Office), $937-955$

Briskin, M., and Schreiber, C., 1978. Authigenic gypsum in marine sediments. Mar. Geol., 28:37-49.

Carothers, W. W., and Kharaka, Y. K., 1978. Aliphatic acid anions in oil field waters-implications for origin of natural gas. Am. Assoc. Pet. Geol. Bull., 62:2441-2453.

Crank, J., 1956. The Mathematics of Diffusion: Oxford (Oxford Univ. Press).

Dickinson, W. R., 1970. Interpreting detrital modes of graywacke and arkose. J. Sed. Petrol., 40:695-707.

Dickson, J. A. D., 1966. Carbonate identification and genesis as revealed by staining. J. Sed. Petrol., 36:491-505.

Dott, R. H., Jr., 1964. Wacke, graywacke and matrix - what approach to immature sandstone classification? J. Sed. Petrol., 34:625-632.

Franks, S. G., and Forester, R. W., 1984. Relationships among secondary porosity, pore-fluid chemistry and carbon dioxide, Texas Gulf Coast. In McDonald, D. A., and Surdam, R. C. (Eds.), Clastic Diagenesis. Am. Assoc. Pet. Geol. Mem., 37:63-80.

Füchtbauer, H., 1972. Diagenesis of arenaceous deposits. In Crawford, F. D. (Ed.), Arenaceous Deposits: Sedimentation and Diagenesis: Edmonton (Univ. Alberta, Dept. of Extension), pp. 205286.

Garrison, R. E., 1981. Diagenesis of oceanic carbonate sediments: a review of the DSDP perspective. In Warme, J. E., Douglas, R. C., and Winterer, E. L. (Eds.), The Deep Sea Drilling Project: A Decade of Progress. Soc. Econ. Paleontol. Mineral., 32:181-207.

Hanor, J. S., 1984. Variation in the chemical composition of oil-field brines with depth in northern Louisiana and southern Arkansas: implications for mechanisms and rates of mass transport and diagenetic reaction. Trans. Gulf Coast Assoc. Geol. Soc., 34:55-61.

Hower, J., Eslinger, E. V., Hower, M. E., and Perry, E. A., 1976. Mechanism of burial metamorphism of argillaceous sediment: 1 . Mineralogical and chemical evidence. Geol. Soc. Am. Bull., 87: $725-737$. 
Hunt, J. M., 1979. Petroleum Geochemistry and Geology: San Francisco (W. H. Freeman and Co.).

Irwin, H., Curtis, C., and Coleman, M., 1977. Isotopic evidence of source of diagenetic carbonates formed during burial of organicrich sediments. Nature, 269:209-213.

Kastner, M., and Siever, R., 1979. Low temperature feldspars in sedimentary rocks. Am. J. Sci., 279:435-479.

Land, L. S., 1984. Frio sandstone diagenesis, Texas Gulf Coast: a regional isotopic study. In McDonald, D. A., and Surdam, R. C. (Eds.), Clastic Diagenesis. Am. Assoc. Pet. Geol. Mem., 37:47-62.

Lewan, M. D., 1985. Evaluation of petroleum generation by hydrous pyrolysis experimentation. Phil. Trans. R. Soc. London, 315:123134.

Leythaeuser, D., Schaefer, R. G., and Yukler, A., 1982. Role of diffusion in primary migration of hydrocarbons. Am. Assoc. Pet. Geol. Bull., 66:408-429.

Loucks, R. G., Dodge, M. M., and Galloway, W. E., 1984. Regional controls on diagenesis and reservoir quality in Lower Tertiary sandstones along the Texas Gulf Coast. In McDonald, D. A., and Surdam, R. C. (Eds.), Clastic Diagenesis. Am. Assoc. Pet. Geol. Mem., 37:15-46.

McCrea, J. M., 1950. On the isotopic chemistry of carbonates and a paleotemperature scale. J. Chem. Phys., 18:849-857.

Manheim, F. T., and Sayles, F. L., 1974. Composition and origin of interstitial waters of marine sediments, based on deep-sea drill cores. In Goldberg, E. D. (Ed.), The Sea (Vol. 5). Marine Chemistry: New York (Wiley-Interscience), 527-568.

Maynard, J. B., 1984. Composition of plagioclase feldspar in modern deep-sea sands: relationship to tectonic setting. Sedimentology, 31: 493-501.

Morse, J. W., 1977. The carbonate chemistry of North Atlantic ocean deep-sea sediment pore water. In Anderson, N. R., and Malahoff, A. (Eds.), The Fate of Fossil Fuel $\mathrm{CO}_{2}$ in the Oceans: New York, (Plenum), pp. 323-343.

O'Neil, J. R., Clayton, R. N., and Mayeda, T. K., 1969. Oxygen isotope fractionation in divalent metal carbonates. J. Chem. Phys., 51:5547-5558.

Pandey, G. N., Tek, M. R., and Katz, D. L., 1974. Diffusion of fluids through porous media with implications in petroleum geology. Am. Assoc. Pet. Geol. Bull., 58:291-303.

Peck, A. J., 1967. Mass transport in porous rocks. Mineralium Deposita, 2:243-247.

Pisciotto, K. A,, and Mahoney, J. J., 1981. Isotopic survey of diagenetic carbonates. In Yeats, R. S., Haq, B. U., et al., Init. Repts. DSDP, 63: Washington (U.S. Govt. Printing Office), 595-609.

Rácz, D., 1971. The role of diffusion transfer in the evolution of heterogeneous reservoir systems. Chem. Geol., 8:171-196.

Reynolds, R. C., and Hower, J., 1970. The nature of interlayering in mixed-layer illite/montmorillonites. Clays Clay Min., 18:25-36.
Robin, P. L., and Rouxhet, P. G., 1978. Characterization of kerogens and study of their evolution by infrared spectroscopy: carbonyl and carboxyl groups. Geochim. Cosmochim. Acta, 42:1341-1349.

Robinson, W. E., 1969. Kerogen of the Green River Formation. In Eglinton, G., and Murphy, M. T. J. (Eds.), Organic Geochemistry: Berlin-Heidelberg-New York (Springer), pp. 619-637.

Roth, P. H., Wise, S. W., and Thierstein, H., 1975. Early chalk diagenesis and lithification: sedimentological applications of paleontological approaches. IXme Congr. Int. Sedimentol., 7:187-192.

Runnels, D. D., 1969. Diagenesis, chemical sediments and the mixing of natural waters. J. Sed. Petrol., 39:1188-1201.

Schlanger, S. O., and Douglas, R. G., 1974. The pelagic-ooze-chalklimestone transition and its implication for marine stratigraphy. In Hsü, K. J., and Jenkyns, H. (Eds.), Pelagic Sediments on Land and Under the Sea: Oxford (Blackwell and Int. Assoc. Sedimentol.), pp. 117-148.

Schmidt, V., and McDonald, D. A., 1979. Texture and recognition of secondary porosity. In Scholle, P. A., and Schluger, P. R. (Eds.), Aspects of Diagenesis: Tulsa (Soc. Econ. Paleontol. Mineral.), pp. 209-225.

Stach, E., 1975. Textbook of Coal Petrology: Berlin-Stuttgart (Gebrüder Borntraeger).

Stout, P. M., 1985. Chemical diagenesis of pelagic biogenic sediments from the equatorial Pacific [Ph.D. dissert]. Univ. California, San Diego.

Surdam, R. C., Boese, S. W., and Crossey, L. J., 1984. The chemistry of secondary porosity. In McDonald, D. A., and Surdam, R. C. (Eds.), Clastic Diagenesis. Am. Assoc. Pet. Geol. Mem., 37:127149.

Tissot, B. P., and Welte, D. H., 1978. Petroleum Formation and Occurrence: New York (Springer-Verlag).

Wilson, M. D., and Pittman, E. D., 1977. Authigenic clays in sandstones: recognition and influence on reservoir properties and paleoenvironmental analysis. J. Sed. Petrol., 47:3-31.

Wise, S. W., Jr., 1977. Chalk formation: early diagenesis. In Anderson, N. R., and Malahoff, A. (Eds.), The Fate of Fossil $\mathrm{CO}_{2}$ in the Oceans: New York (Plenum), pp. 717-739.

Wood, J. R., and Hewett, T. A., 1982. Fluid convection and mass transfer in porous sandstones-a theoretical model. Geochem. Cosmochim. Acta, 46:1707-1713.

, 1984. Reservoir diagenesis and convective fluid flow. In McDonald, D. A., and Surdam, R. C. (Eds.), Clastic Diagenesis. Am. Assoc. Pet. Geol. Mem., 37:99-110.

Date of Initial Receipt: 16 April 1985

Date of Acceptance: 16 December 1985 